\title{
Pengaruh Likuiditas dan Profitabilitas Terhadap Harga Saham Pada Perusahaan Manufaktur Sub Sektor Makanan dan Minuman di Bursa Efek Indonesia
}

\author{
Andis', Mahfudnurnajamuddin ${ }^{2}$, Suriyanti ${ }^{3}$ \\ ${ }^{1}$ Magister Manajemen Pascasarjana, Universitas Muslim Indonesia \\ 2,3 Magister Manajemen Pascasarjana, Universitas Muslim Indonesia
}

Email Korespondensi: andisse32@gmail.com

\begin{abstract}
Abstrak
Penelitian bertujuan untuk menguji pengaruh likuiditas dan profitabilitas terhadap harga saham perusahaan manufaktur sub sector makanan dan minuman yang terdaftar di Bursa Efek Indonesia (BEI). Pendekatan penelitian yang digunakan dalam penulisan merupakan penelitian deskriptif dengan pendekatan kuantitatif. Yang dimaksud dengan penelitian deskriptif adalah penelitian yang berusaha untuk menuturkan pemecahan masalah yang ada sekarang berdasarkan data-data yang ada. Jadi penelitian deskriptif juga menyajikan datadata, menganalisis dan menginterpretasikan. Tujuan dari penelitian deskriptif ini adalah membuat deskriptif, gambaran atau lukisan secara sistematis serta hubungan antar fenomena yang diselidiki. Sedangkan yang dimaksud dengan pendekatan kuantitatif adalah pendekatan yang digunakan dalam penelitian dengan cara mengukur indikator-indikator variabel penelitian sehingga diperoleh gambaran diantara variabel-variabel tersebut. Adapun yang menjadi lokasi atau objek penelitian ini di lakukan pada Bursa Efek Indonesia melalui webset www.idx.co.id melalui geleri Bursa Efek Universitas Muslim Indonesia, dengan jangka waktu penelitian selama dua bulan, dari bulan Februari tahun 2021 sampai bulan April tahun 2021. Data yang digunakan dalam penelitian ini adalah data sekunder. Berdasarkan hasil penelitian dan pembahasan, maka dapat ditarik simpulan bahwa secara parsial variabel CR, EPS, ROI, dan ROE tidak berpengaruh signifikan terhadap harga saham pada perusahaan manufaktur sub sector makanan dan minuman di Bursa Efek Indonesia (BEI) tahun 2015-2019. Secara simultan variabel CR, EPS, ROI, dan ROE berpengaruh negatif dan tidak signifikan terhadap harga saham pada perusahaan manufaktur sub sector makanan dan minuman di Bursa Efek Indonesia (BEI) tahun 2015-2019.
\end{abstract}

Kata Kunci: Rasio Likuiditas, Rasio Profitabilitas, Harga Saham

\section{Pendahuluan}

Perkembangan pengetahuan dan teknologi membuat kemudahan dalam akses bisnis. Salah satu cara perusahaan dalam memperoleh sumber pendanaan adalah dengan listing di pasar modal. Pasar modal di Indonesia membuka peluang bagi perusahaan untuk melakukan listing di pasar modal yang memudahkan perusahaan memperoleh dana (Darmadji \& Hendy, 2006). Perusahaan berusaha untuk menarik minat investor dalam melakukan investasi, maka manajemen perusahaan harus mengelola sumber daya perusahaan secara maksimal, sehingga dapat meningkatkan harga saham perusahaan. Sebelum melakukan investasi, terlebih dahulu mereka melakukan analisis terhadap laporan keuangan yang dibuat oleh manajemen perusahaan. Analisis terhadap laporan keuangan diperlukan untuk mengetahui sejauh mana prospek perusahaan di masa yang akan datang (Apriliana, 2019).

Perusahaan makanan dan minuman memiliki prospek yang cukup bagus dan cenderung diminati oleh investor sebagai salah satu target investasinya. Penyebabnya adalah hasil industri ini cenderung digemari oleh masyarakat seperti makanan ringan, minuman energi, minuman isotonik serta minuman dalam kemasan (Arfah \& Aditya, 2019). Perusahaan makanan dan minuman merupakan kategori barang konsumsi perusahaan manufaktur dimana produknya sangat dibutuhkan masyarakat, sehingga prospek menguntungkan baik dimasa sekarang maupun dimasa yang akan datang, selain itu saham perusahaan tersebut merupakan saham yang paling tahan krisis ekonomi dibandingkan dengan sektor lain karena dalam kondisi krisis atau tidak sebagian besar produk 
makanan dan minuman tetap dibutuhkan masyarakat. Selain itu karakteristik dari masyarakat yang cenderung gemar berbelanja makanan, dapat membantu mempertahankan. Sehingga saham pada perusahaan makanan dan minuman lebih banyak menarik minat investor. Menurut Broadstock et al. (2020) salah satu hal yang harus menjadi fokus pertimbangan seorang investor adalah harga saham. Harga saham yang diharapkan investor adalah harga saham yang stabil dan mempunyai pola pergerakan yang cenderung naik dari waktu ke waktu. Harga saham yang terjadi di pasar modal ditentukan oleh pelaku pasar. Harga saham merupakan harga yang berlaku sekarang dimana saham diperdagangkan. Rasio profitabilitas yakni rasio yang menilai kemampuan perusahaan dalam mencari keuntungan (Mait et al., 2013). Rasio ini dapat juga memberikan ukuran tingkat efektivitas manajemen suatu perusahaan. Hal ini ditunjukkan oleh adanya laba yang dihasilkan dari penjuaan dan pendapatan investasi. Inti dari penggunaan rasio ini adalah untuk menunjukkan efisiensi perusahaan.

Perusahaan sub sektor makanan dan minuman merupakan salah satu Sektor perusahaan industri manufaktur yang terdaftar di Bursa Efek Indonesia. Potensi industri makanan dan minuman di Indonesia bisa menjadi juara, karena supply dan user-nya banyak. Kunci daya saing pada sektor ini adalah inovasi dan keamanan produk. Kementerian Perindustrian mencatat sepanjang tahun 2018, industri makanan dan minuman mampu tumbuh sebesar 7,91\% atau melampaui pertumbuhan ekonomi nasional di angka 5,17\%. Industri makanan dan minuman dapat bertahan tidak bergantung pada bahanbaku impor dan lebih banyak menggunakan bahan baku domestik. Selain itu, karakteristik masyarakat cenderung gemar berbelanja makanan, ikut membantu mempertahankan industri makanan dan minuman. Meningkatnya harga saham sub-sektor makanan dan minuman, hal ini disebabkan karena produk makanan dan minuman yang diproduksi di Tanah Air banyak digemari dibeberapa Negara lain, misalnya mi instan yang sangat digemari di Negara-negara Afrika. Upaya untuk mendorong pertumbuhan sektor itu antara lain dengan aktif menciptakan iklim investasi yang kondusif. Kalau dilihat dari perkembangan realisasi investasi untuk sektor makanan dan minuman triwulan III/2017 mencapai Rp.27,92 triliun atau meningkat 16,3\% dibandingkan periode yang sama tahun 2016 untuk penanaman modal dalam dalam negeri dan USD 1,46 miliar untuk penanaman modal asing. Tinggi atau rendahnya suatu saham, ditentukan oleh harga dari saham tersebut, harga saham mencerminkan semua informasi yang ada di masyarakat sehubungan dengan nilai perusahaan. sehingga Harga saham merupakan salah satu indikator yang menunjukkan minat dari investor untuk memiliki saham suatu perusahaan. Jika harga saham perusahaan mengalami kenaikan, maka investor menilai perusahaan tersebut memiliki prestasi yang baik, demikian juga sebaliknya (Kewal, 2012). Teori signal (Signalling theory) yang dipelopori Ross (1977) menjelaskan bahwa perusahaan memberikan sinyal kepada investor berupa informasi laporan keuangan dan bagaimana manajemen memandang prospek perusahaan di masa yang akan datang. Informasi yang dipublikasikan sebagai suatu pengumuman akan memberikan sinyal bagi investor dalam pengambilan keputusan investasi (Hery, 2016).

Pemilihan variable profitabilitas disebabkan karena profitabilitas merupakan kemampuan suatu perusahaan dalam menghasilkan laba, dimana para investor dan kreditur sangat memperhatikan dalam mengevaluasi kemampuan perusahaan dalam meghasilkan laba saat ini maupun dimasa mendatang. Hal ini disebabkan karena Profitabilitas merupakan salah satu pengukuran bagi kinerja suatu perusahaan sejauh mana dapat menghasikan laba. Semakin tinggi profitabilitas maka semakin tinggi kemampuan perusahaan menghasilkan laba maka semakin meningkat pula dividen yang dibagikan dan akan meningkatkan harga saham. Profitabilitas dalam penelitian ini proksikan oleh Return on asset (ROA) Dalam hal ini ROA digunakan bagi investor untuk melihat seberapa jauh kemampuan perusahaan dalam mengelolah modal sendiri untuk menghasilkan laba (Saerang \& P.E., 2010). Semakin besar perubahan ROA menunjukan semakin besar fluktuasi kemampuan manajemen dalam menghasilkan laba. Hal ini mempengaruhi investor dalam memprediksi laba dan memprediksi risiko dalam investasi sehingga memberi dampak pada kepercayaan investor dalam memprediksi perubahan (Ishak \& Luthfi, 2011). Pemanfaatan teori tersebut didukung olen beberapa temuan peneliti terdahulu. bahwa ROA berpengaruh positif dan tidak signifikan terhadap harga saham (Edwar, 2016). Temuan tersebut berbeda dengan temuan peneliti lainnya (Kim, 2020) menyatakan bahwa ROA berpengaruh negatif dan signifikan terhadap harga saham. Fakta empiris yang diperoleh menunjukkan pergerakan harga saham emiten untuk sub-sektor ini menunjukkan peningkatan untuk tahun data 2017-2018. 
Pemilihan likuiditas disebabkan karena likuiditas merupakan suatu indikator yang dapat menunjukan kondisi perusahaan yang dilihat dari bagaimana menggambarkan tentang kemampuan perusahaan untuk membayar semua kewajiban jangka pendeknya dengan aktiva yang ada dan memberikan suatu gambaran apakah peruahaan tersebut dapat memenuhi seluruh kewajibankewajibannya yang telah jatuh tempo. Likuiditas diproksikan oleh Current ratio, alasan menggunakan CR karena digunakan untuk mengukur kemampuan perusahaan dalam membayar kewajiban finansial jangka pendek. Oleh karenanya penulis pun merasa tertarik untuk melakukan penelitian untuk menguji pengaruh likuiditas dan profitabilitas terhadap harga saham perusahaan manufaktur sub sector makanan dan minuman yang terdaftar di Bursa Efek Indonesia (BEI).

\section{Tabel 1: Rumusan dan Tujuan Penelitian}

\section{Rumusan Masalah}

1. Apakah Current Ratio (CR) berpengaruh signifikan terhadap harga saham perusahaan manufaktur yang terdaftar di Bursa Efek Indonesia?

2. Apakah Earnings Per-Share (EPS), Return on Investment (ROI), dan Return on Equity (ROE) berpengaruh signifikan terhadap harga saham perusahaan manufaktur yang terdaftar di Bursa Efek Indonesia?

3. Apakah Current Ratio (CR), Earnings Per-Share (EPS), Return on Investment (ROI), dan Return on Equity (ROE) secara bersama-sama berpengaruh signifikan terhadap harga saham perusahaan manufaktur yang terdaftar di Bursa Efek Indonesia?

\section{Tujuan Penelitian}

1. Menganalisis seberapa besar pengaruh Current Ratio (CR) terhadap harga saham perusahaan manufaktur yang terdaftar di Bursa Efek Indonesia.

2. Menganalisis seberapa besar pengaruh Earnings Per-Share (EPS) terhadap harga saham perusahaan manufaktur yang terdaftar di Bursa Efek Indonesia.

3. Menganalisis seberapa besar pengaruh Current Ratio (CR) dan Earnings Per-Share (EPS) secara bersama-sama terhadap harga saham perusahaan manufaktur yang terdaftar di Bursa Efek Indonesia.

\section{Tinjauan Pustaka}

\section{A. Harga Saham dan faktor yang memengaruhi harga saham}

Harga saham suatu perusahaan mencerminkan nilai dari perusahaan tersebut. Harga saham merupakan nilai yang diperdagangkan di bursa efek. Peningkatan maupun penurunan harga saham disebabkan oleh faktor permintaan dan penawaran saham tersebut. Jika investor banyak melakukan penawaran saham maka akan menyebabkan harga saham menurun dan jika investor banyak melakukan permintaan terhadap harga saham perusahaan maka harga saham perusahaan tersebut akan meningkat. Adapun nilai Saham menurut Guerrazzi (2015) terbagi atas tiga jenis yaitu: (a) Nilai Buku, (b) Harga Pasar, (c) Nilai Intrinsik. Ada beberapa variabel yang berhubungan dengan harga saham. Variabel-variabel tersebut adalah: (a) Return on Asset (ROA), (b) Book Value (BV), (c) Earning per Share (EPS), (c) Debt to Equity Ratio (DER), (c) Tingkat Suku Bunga Diskonto, (d) Return on Equity (ROE), (e) Tingkat Bunga Bebas Risiko, (f) Tingkat Bunga Pasar, (g) Risiko Pasar, (h) Likuiditas. Rasio likuiditas merupakan suatu indikator mengenai kemampauan perusahaan membayar semua kewajiban fianansial jangka pendek pada saat jatuh tempo dengan menggunakan aktiva lancar yang tersedia. Likuiditas tidak hanya berkenaan dengan keadaan keseluruhan keuangan perusahaan, tetapi juga berkaitan dengan kemampuannya mengubah aktiva lancar tertentu menjadi uang kas. Likuiditas adalah masalah yang berhubungan dengan masalah kemampuan suatu perusahaan untuk segera memenuhi kewajiban financialnya (Hery, 2016). Suatu perusahaan yang mempunyai alat-alat likuid sedemikian besarnya sehingga mampu memenuhi segala kewajiban financialnya yang segera harus terpenuhi, dikatakan bahwa perusahaan tersebut likuid, dan sebaliknya apabila suatu perusahaan tidak mempunyai alat-alat likuid yang cukup untuk memenuhi segala kewajiban financialnya yang segera harus terpenuhi dikatakan perusahaan tersebut insolvable. Likuiditas mengacu pada ketersediaan sumber daya perusahaan untuk memenuhi kebutuhan kas jangka pendek. Likuiditas perusahaan yang sering kali diukur menggunakan rasio lancar menunjukkan kemampuan perusahaan mendanai operasional perusahaan dan melunasi kewajiban jangka pendeknya. Rasio likuiditas adalah rasio yang mengukur kemampuan perusahaan memenuhi kewajiban jangka pendeknya. Rasio-rasio ini dapat dihitung melalui sumber informasi tentang modal kerja yaitu pospos aktiva lancar dan hutang lancar. Dengan demikian rasio likuiditas berpengaruh dengan kinerja keuangan perusahaan sehingga rasio ini memiliki hubungan dengan harga saham perusahaan. 
Current ratio merupakan perbandingan antara aktiva lancar dan kewajiban lancar dan merupakan ukuran yang paling umum digunakan untuk mengetahui kesanggupan suatu perusahaan memenuhi kewajiban jangka pendeknya. Current ratio menunjukkan sejauh mana akitva lancar menutupi kewajiban-kewajiban lancar (Öztürk, 2017). Semakin besar perbandingan aktiva lancar dan kewajiban lancar semakin tinggi kemampuan perusahaan menutupi kewajiban jangka pendeknya. Current ratio yang rendah biasanya dianggap menunjukkan terjadinya masalah dalam likuidasi, sebaliknya current ratio yang terlalu tinggi juga kurang bagus, karean menunjukkan banyaknya dana menganggur yang pada akhirnya dapat mengurangi kemampulabaan perusahaan. Apabila mengukur tingkat likuiditas dengan menggunakan current ratio sebagai alat pengukurnya, maka tingkat likuiditas atau current ratio suatu perusahaan dapat dipertinggi dengan cara: (1) Dengan utang lancar tertentu, diusahakan untuk menambah aktiva lancar. (2) Dengan aktiva lancar tertentu, diusahakan untuk mengurangi jumlah utang ancar. (3) Dengan mengurangi jumlah utang lancar sama-sama dengan mengurangi aktiva lancar (Tangngisalu et al., 2020).

\section{B. Profitabilitas}

Rasio profitabilitas yakni Rasio yang menilai kemampuan perusahaan dalam mencari keuntungan. Rasio ini dapat juga memberikan ukuran tingkat efektivitas manajemen suatu perusahaan. Hal ini ditunjukkan oleh adanya laba yang dihasilkan dari penjuaan dan pendapatan investasi. Inti dari penggunaan rasio ini adalah untuk menunjukkan efisiensi perusahaan. Adapun Rasio ini mengukur efektivitas manajemen secara keseluruhan yang ditujukan oleh besar kecilnya tingkat keuntungan yang diperoleh dalam hubungannya dengan penjualan maupun investasi (W.Wahyuni, 2012). Rasio profitabilitas adalah rasio yang mengukur kemampuan perusahaan menghasilkan keuntungan (profitabilitas) pada tingkat penjualan, aset, dan modal saham yang tertentu. Dalam penelitian ini profitabilitas diproksikan oleh Return on assets (ROA) yaitu Return On Assets (ROA) menunjukkan kemampuan perusahaan menghasilkan laba dari aktiva yang dipergunakan Adapun rumus Return On Assets (ROA). Rasio profitabilitas adalah rasio yang digunakan untuk mengukur efektifitas manajemen berdasarkan hasil pengembalian dari penjualan investasi serta kemampuan perusahaan menghasilkan laba yang akan menjadi dasar pembagian dividen perusahaan (Tahir \& Mushtaq, 2016). Earning Per Share (EPS) menunjukkan besarnya laba bersih yang siap dibagikan kepada para pemegang saham. Semakin tinggi nilai EPS dapat diartikan bahwa semakin besar pula laba yang disediakan untuk pemegang saham. Return On Investment (ROI) merupakan salah satu metode yang digunakan untuk penilaian prestasi pusat investasi, dengan cara membandingkan ROI yang dicapai oleh investasi yang bersangkutan dengan Return On investment yang diharapkan. Return on Equity (ROE) merupakan rasio antara laba bersih setelah pajak terhadap penyertaan modal sendiri, yang berarti juga merupakan ukuran untuk menilai seberapa besar tingkat pengembalian dari saham sendiri yang ditanamkan dalam bisnis. Return on Equity menggambarkan sejauh mana kemampuan perusahaan menghasilkan laba yang bisa diperoleh pemegang saham. Berdasarkan pendapat-pendapat para ahli tersebut maka dapat disimpulkan bahwa rasio profitabilitas adalah kemampuan suatu perusahaan untuk mencapai laba dalam hubungannya dengan penjualan, total aktiva, maupun modal sendiri. Semakin tinggi profitabilitas perusahaan semakin tinggi efisiensi perusahaan tersebut dalam memanfaatkan

\section{Signaling Theory (Teori Signal)}

Signaling Theory mengemukakan konsep teori signal pertama kali dipelajari dalam konteks pasar tenaga kerja dan pasar barang oleh Akerlof dan Arrow dan dikembangkan menjadi teori keseimbangan signal oleh Spence (Morris, 1987). Teori signal menurut Morris (1987) menjelaskan masalah asimetris informasi dalam pasar. Teori ini menunjukkan bagaimana asimetris ini dapat dikurangi dengan memberikan lebih banyak signal informasi kepada pihak lain. Walaupun dikembangkan dalam pasar tenaga kerja, teori signal merupakan fenomena umum yang dapat diaplikasikan dalam setiap pasar dengan asimetris informasi termasuk dalam pasar modal. Asimetris informasi dalam pasar modal dapat terjadi karena pihak perusahaan memiliki informasi yang lebih banyak dibandingkan dengan pihak eskternal perusahaan. Sukirno (2003) mengatakan teori signal berbicara mengenai manajer yang menggunakan akun-akun dalam laporan keuangan untuk memberikan tanda atau signal harapan dan tujuan masa depan. Menurut teori ini, jika manajer mengharapkan suatu tingkat pertumbuhan perusahaan yang tinggi di masa depan, mereka akan 
berusaha memberikan signal itu terhadap investor melalui akun-akun. Manajer dari perusahaan lain yang memiliki kinerja yang baik akan memiliki insentif yang sama, dan manajer dari perusahaan dengan kinerja rata-rata akan memiliki insentif untuk melaporkan berita yang positif sehingga mereka tidak dianggap berkinerja buruk. Manajer dari perusahaan dengan kinerja buruk umumnya akan berinisiatif untuk tidak melaporkannya, tetapi mereka juga memiliki insentif untuk melaporkan kinerja buruknya untuk mempertahankan kredibilitas dalam pasar saham. Mengasumsikan insentifinsentif tersebut untuk memberikan signal informasi pada pasar modal, teori signal memprediksi bahwa perusahaan akan mengungkapkan lebih banyak dari yang diharuskan. Konsekuensi logis dari teori signal adalah ada banyak insentif untuk seluruh manajer untuk memberikan signal harapan keuntungan masa depan karena jika investor mempercayai signal tersebut, harga saham akan naik dan pemegang saham akan diuntungkan. Dengan adanya asimetris informasi dalam pasar modal dimana pihak perusahaan memiliki informasi yang lebih banyak dibandingkan dengan pihak eskternal perusahaan, maka Badan Pengawas Pasar Modal (BAPEPAM) sebagai pengawas jalannya pasar modal, berusaha mengatasinya dengan mengharuskan setiap perusahaan yang terdaftar dalam bursa saham mengeluarkan laporan keuangan secara periodik untuk memberikan informasi kepada pihak eksternal perusahaan, terutama pihak investor. Berdasarkan pembahasan teori signal diatas, pihak internal perusahaan atau manajemen membuat dan mempublikasikan laporan keuangan dengan tujuan memberikan signal kepada investor mengenai kinerja mereka. Pemberian signal mengenai kinerja mereka diharapkan dapat menarik investor untuk berinvestasi pada perusahaan mereka dengan menggunakan laporan keuangan sebagai pertimbangan mereka. Dengan laporan keuangan menjadi bahan pertimbangan investor, maka investor akan melakukan analisis terhadap laporan keuangan. Salah satu alat analisis laporan keuangan adalah analisis rasio keuangan. Analisis rasio keuangan terdiri dari rasio likuiditas, aktivitas, leverage, dan profitabilitas (Magrizos et al., 2020; Yanikkaya et al., 2018). Bila hasil analisis laporan keuangan menunjukkan kinerja perusahaan yang baik, maka investor akan tertarik untuk membeli saham perusahan yang bersangkutan dan dapat meningkatkan harga saham perusahaan di pasar modal.

\section{Analisis Laporan Keuangan}

Analisis laporan keuangan adalah seni untuk mengubah data dari laporan keuangan ke informasi yang berguna bagi pengambilan keputusan. Analisis keuangan melibatkan penggunaan berbagai laporan keuangan (Eprima Dewi et al., 2015). Laporan ini melaksanakan melaksanakan beberapa fungsi. Pertama, laporan posisi keuangan atau neraca meringkas aset, liabilities, dan ekuitas pemilik suatu perusahaan pada suatu periode, biasanya pada akhir tahun atau kuartal. Sementara laporan laba rugi meringkas pendapatan dan biaya perusahaan selama suatu periode waktu tertentu. Analisis laporan keuangan perlu dilakukan berbagai pihak sehingga laporan keuangan lebih berarti. Laporan keuangan juga akan memberikan informasi tentang kelemahan dan kekuatan yang dimiliki perusahaan (Lynch et al., 2012). Laporan keuangan tidak akan memberikan makna jika tidak dilakukan analisis lebih jauh terhadap angka- angka yang terdapat didalamnya. Angka-angka dalam laporan keuangan selanjutnya saling dihubungkan sehingga membentuk rasio keuangan. Analisis laporan keuangan dilakukan agar informasi yang ada dalam laporan keuangan menjadi lebih bermakna bagi keperluan pemakai laporan keuangan untuk membuat keputusan ekonomi.

\section{E. Laporan Keuangan}

Tujuan Laporan Keuangan Menurut Statement of Financial Accounting Concepts No. 1 (FASB, 1978) yang dikeluarkan oleh FASB, tujuan dari laporan keuangan (financial statements) adalah sebagai berikut: (1) Laporan keuangan menyajikan informasi yang berguna bagi calon investor dan kreditor serta pengguna lainnya dalam membuat keputusan investasi, kredit dan keputusan sejenis lainnya. (2) Laporan keuangan menyediakan informasi yang membantu calon investor dan kreditor serta pengguna lainnya dalam menentukan jumlah, waktu, dan ketidakpastian dari proyeksi penerimaan kas dari dividen atau bunga dan penerimaan dari penjualan, pelunasan, atau jatuh temponya sekuritas atau pinjaman. (3) Laporan keuangan menyediakan informasi mengenai sumber daya ekonomis dari perusahaan, klaim terhadap sumber daya (kewajiban perusahaan untuk memberikan sumber daya kepada pihak lain atau pemilik ekuitas) dan dampak dari transaksi, kejadian, dan kondisi yang mengubah sumber daya dan klaim terhadap sumber daya tersebut. Menurut Pernyataan Standar Akuntansi Keuangan No. 1 Par. $39-76$ (IAI, 2009) laporan keuangan 
terdiri dari komponen-komponen sebagai berikut: (1) Neraca, (2) Laporan Laba Rugi, (3) Laporan Perubahan Ekuitas, (4) Laporan Arus Kas, (5) Catatan Atas Laporan Keuangan.

\section{F. Analisis Rasio Keuangan}

Langkah pertama dalam melakukan analisis laporan keuangan adalah untuk secara teliti membaca pernyataan dan catatan yang mendampinginya. Hal ini umumnya diikuti oleh analisis rasio. Setelah menghitung rasio keuangan pada perioda berjalan, umumnya perusahaan ataupun pengguna informasi melakukan perbandingan dengan rasio perioda sebelumnya, rasio perusahaan lain ataupun rasio industri secara keseluruhan (Asna \& Graha, 2006; Lukiana, 2013; Mait et al., 2013; W.Wahyuni, 2012). Secara umum analis menggunakan rasio sebagai salah satu cara dalam mengidentifikasi kekuatan atau kelemahan perusahaan. Rasio keuangan secara umum dapat terbagi menjadi empat jenis, yaitu:

1. Rasio Likuiditas merupakan rasio keuangan yang mengukur kemampuan perusahaan untuk membayar kewajiban jangka pendeknya pada saat jatuh tempo. Rasio ini mengasumsikan bahwa aktiva lancar merupakan sumber uang utama untuk memenuhi kewajiban jangka panjangnya. Rasio-rasio yang termasuk rasio likuiditas adalah:

2. Current Ratio, merupakan perbandingan antara jumlah aktiva lancar dengan hutang lancar (. Pemberi pinjaman umumnya mengharuskan current ratio perusahaan pada nilai 2.0 atau lebih sebagai syarat untuk memperoleh atau melanjutkan pinjaman.

3. Quick Ratio, sering disebut acid-test ratio merupakan perbandingan aktiva lancar (tanpa persediaan) terhadap hutang lancar. Quick ratio mengukur kemampuan perusahaan membayar kewajiban jangka pendeknya dengan mengubah aktiva yang paling likuid menjadi uang kas. Standar quick ratio harus sama dengan atau lebih dari 1,0.

4. Cash Ratio, adalah rasio yang membandingkan antara kas dan aktiva lancar yang bisa segera menjadi uang kas dengan hutang lancar. Aktiva lancar yang bisa segera menjadi uang kas adalah efek atau surat berharga.

5. Rasio Aktivitas, mengukur tingkat efisiensi perusahaan dalam penggunaan sumber dayanya. Aktiva sebagai penggunaan dana seharusnya dapat dikendalikan agar dapat dimanfaatkan secara optimal. Semakin efektif dalam memanfaatkan dana, semakin cepat perputaran dana tersebut, karena rasio aktivitas umumnya diukur dari perputaran masing-masing aktiva. Rasio-rasio yang termasuk rasio aktivitas adalah: Inventory Turnover, atau perputaran persediaan merupakan rasio antara jumlah harga pokok barang yang dijual dengan nilai ratarata persediaan yang dimiliki oleh perusahaan. Total Assets Turnover, Rasio total assets turnover mengukur hubungan antara jumlah penjualan dengan jumlah aktiva, umumnya dengan dasar tahunan. Rasio ini mengukur seluruh aktivitas perusahaan. Rasio ini dapat digunakan untuk mengukur tingkat penjualan yang dihasilkan perusahaan dibandingkan dengan kapasitas produksinya. Fixed Assets Turnover, Rasio perputaran aktiva tetap atau fixed assets turnover merupakan perbandingan antara penjualan bersih dengan total aktiva tetap yang dimiliki perusahaan. Rasio ini digunakan untuk mengukur efektivitas penggunaan aktiva tetap dalam mendapatkan penghasilan atau penjualan. Average Collection Period, piutang dagang berubah seiring berjalannya operasi perusahaan. Rasio average collection period mengukur rata-rata jumlah hari yang diperlukan perusahaan untuk menagih piutang dagangnya (Martani \& Khairurizka, 2009).

6. Rasio Hutang atau Leverage, menunjukkan seberapa besar kebutuhan dana perusahaan dibelanjai dengan hutang. Apabila perusahaan tidak mempunyai leverage atau rasio leverage-nya bernilai nol, artinya perusahaan beroperasi sepenuhnya menggunakan modal sendiri tanpa menggunakan hutang. Dalam rasio hutang ini pertama, berpusat pada bagian kewajiban dan ekuitas pemegang saham dalam neraca dan mengukur seberapa jauh perusahaan membiayai sendiri ekuitasnya, dan kedua, mengukur kemampuan perusahaan untuk menghasilkan tingkat pendapatan yang cukup untuk memenuhi kewajiban obligasi. Rasio yang termasuk kelompok pertama adalah debt to equity ratio dan total debt to total assets ratio. Rasio yang termasuk kelompok kedua adalah times interest earned ratio. Debt Equity Ratio, Semakin tinggi rasio ini, berarti modal sendiri semakin sedikit dibandingkan dengan hutangnya. Umumnya besar hutang maksimal sama dengan modal sendiri, artinya debt to equity ratio maksimal bernilai $100 \%$ atau 1,0. Total Debt to Total Assets Rasio, Rasio ini dikenal 
juga dengan nama debt ratio. Rasio ini mengukur persentase total dana yang disediakan oleh utang. Dengan mengurangi persentase ini dari 1,0 akan diperoleh persentase total dana yang disediakan oleh ekuitas. Rasio ini dihitung dengan membagi total kewajiban dengan total aktiva. Times Interest Earned Ratio, Rasio ini mengukur kemampuan perusahaan untuk membayar bunga atas pinjamannya. Secara implisit rasio ini mengasumsikan bahwa pendapatan yang tersisa (setelah penjualan bersih dikurangi biaya produksi, operasi dan administrasi) mampu untuk menutupi biaya bunga.

\section{G. Kerangka Konseptual}

Dalam penelitian ini terdapat 4 rasio yang digunakan yaitu Current Ratio (CR), Earning Per Share (EPS), Return on Investment (ROI), dan Return on Equity (ROE) yang akan diuji pengaruhnya terhadap harga saham. Jika hal ini dibentuk ke dalam model penelitian, maka akan terbentuk gambar seperti di bawah ini:

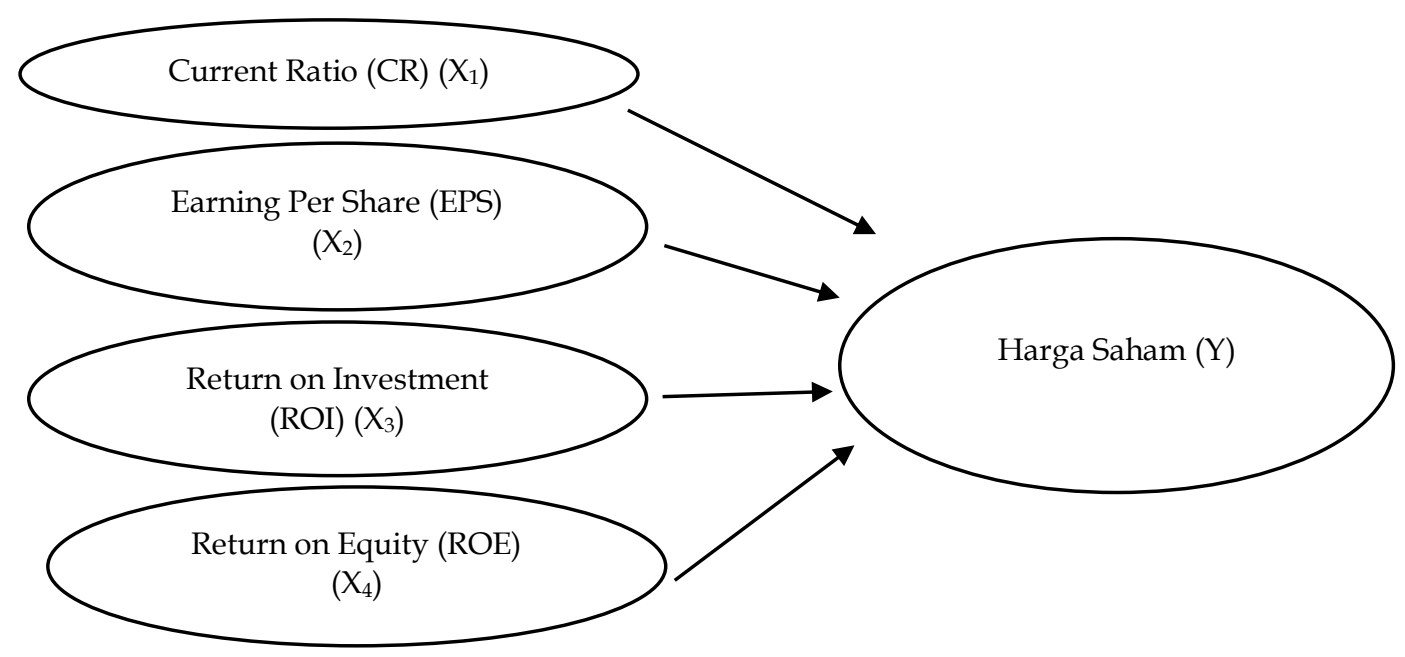

\section{Gambar 1. Kerangka Konseptual}

Berdasarkan rumusan masalah dan kerangka konseptual tersebut di atas, maka hipotesis, yang diajukan dalam penelitian ini adalah:

1. Diduga bahwa Current Ratio (CR) berpengaruh signifikan terhadap harga saham perusahaan manufaktur di Bursa Efek Indonesia.

2. Diduga bahwa Earnings Per-Share (EPS), Return on Investment (ROI), dan Return on Equity (ROE) berpengaruh signifikan terhadap harga saham perusahaan manufaktur di Bursa Efek Indonesia.

3. Diduga bahwa Current Ratio (CR), Earnings Per-Share (EPS), Return on Investment (ROI), dan Return on Equity (ROE) secara bersama-sama berpengaruh signifikan terhadap harga saham perusahaan manufaktur di Bursa Efek Indonesia.

\section{Metode Penelitian}

Pendekatan penelitian yang digunakan dalam penulisan merupakan penelitian deskriptif dengan pendekatan kuantitatif. Yang dimaksud dengan penelitian deskriptif adalah penelitian yang berusaha untuk menuturkan pemecahan masalah yang ada sekarang berdasarkan data-data yang ada. Jadi penelitian deskriptif juga menyajikan data-data, menganalisis dan menginterpretasikan. Tujuan dari penelitian deskriptif ini adalah membuat deskriptif, gambaran atau lukisan secara sistematis serta hubungan antar fenomena yang diselidiki. Sedangkan yang dimaksud dengan pendekatan kuantitatif adalah pendekatan yang digunakan dalam penelitian dengan cara mengukur indikator-indikator variabel penelitian sehingga diperoleh gambaran diantara variabel-variabel tersebut. Adapun yang menjadi lokasi atau objek penelitian ini di lakukan pada Bursa Efek Indonesia melalui webset www.idx.co.id melalui geleri Bursa Efek Universitas Muslim Indonesia, dengan jangka waktu 
penelitian selama dua bulan, dari bulan Februari tahun 2021 sampai bulan April tahun 2021. Data yang digunakan dalam penelitian ini adalah data sekunder. Data sekunder yaitu data yang diperoleh secara tidak langsung dari buku-buku referensi, jurnal ekonomi, www.idx.co.id melalui geleri Bursa Efek Universitas Muslim Indonesia Makassar, dan peneliti-peneliti sebelumnya yang berkaitan dengan penelitian ini. Data-data yang akan digunakan dalam penelitian ini terdiri dari: (1) Data laporan keuangan publikasi tahunan (annual report) masing-masing perusahaan dengan tahun fiskal yang berakhir 31 Desember, yang terdiri dari Aktiva lancar, labilitas jangka pendek, total ekuitas, laba setelah pajak, total aktiva dan jumlah saham yang beredar dengan periode tahun 2015-2019. (2) Data harga saham yang digunakan adalah harga saham pada saat penutupan (closing price) di peroleh dari Bursa Efek Indonesia periode tahun 2015-2019. (3) Laporan keuangan tahun 2015-2019 untuk masingmasing perusahaan diakses dan di download penulis dari website Bursa Efek Indonesia (www.idx.co.id).

Metode yang digunakan dalam pengumpulan data pada penelitian ini adalah metode Studi Pustaka, yang diperoleh dari buku-buku referensi, jurnal ekonomi, www.idx.co.id melalui galeri Bursa Efek Universitas Muslim Indonesia Makassar, dan peneliti-peneliti sebelumnya yang berkaitan dengan penelitian ini. Populasi adalah wilayah generalisasi yang terdiri atas obyek atau subyek yang mempunyai kualitas dan karakteristik tertentu yang ditetapkan oleh peneliti untuk dipelajari dan kemudian ditarik kesimpulannya. Adapun populasi yang diambil dalam penelitian ini adalah Aktiva lancar, labilitas jangka pendek, total ekuitas, laba setelah pajak, total aktiva dan jumlah saham yang beredar, yang di peroleh dari www.idx.co.id melalui geleri Bursa Efek Universitas Muslim Indonesia Makassar. Sampel merupakan bagian dari poulasi yang memiliki ciri atau keadaan tertentu yang akan diteliti. Sampel merupakan anggota populasi yang dipilih dengan mengunkan teknik atau metode penentuan sampel tertentu. Berikut adalah Perusahaan-perusahaan manufaktur sub sektor makanan dan minuman yang terdaftar di Bursa Efek Indonesia yang menjadi sampel dalam penelitian ini: (1) PT Akasha Wira International Tbk; (2) PT Tiga Pilar Sejahtera Food Tbk; (3) PT Wilmar Cahaya Indonesia Tbk; (4) PT Delta Djakarta Tbk; (5) PT Indofood CBP Sukses Makmur Tbk; (6) PT Mayor Indah Tbk; (7) PT Nippon Indosari Corpindo Tbk; (8) PT Ultrajaya Milk Industry \& Trading Co. Tbk; (9) PT Indofood Sukses Makmur Tbk; (10) PT Multi Bintang Indonesia Tbk; (11) PT Sekar Bumi Tbk; (12) PT Sekar Laut Tbk; (13) PT Siantar Top Tbk. Dalam melakukan analisis data, digunakan program SPSS (Statistical Product and Service Solutions) versi 12.0 untuk Windows. Sebelum melakukan analisis regresi, data-data yang digunakan harus lolos dari empat uji asumsi klasik untuk model regresi yaitu uji asumsi klasik diantaranya Uji Normalitas, menurut Sugiyono (2017:239), "uji normalitas digunakan untuk mengkaji kenormalan variabel yang diteliti apakah data tersebut berdistribusi normal atau tidak". Hal tersebut penting karena bila data setiap variabel tidak normal, maka pengujian hipotesis tidak bisa menggunakan statistik parametrik. Uji Multikolienaritas, menurut Ghozali (2016:82), "uji multikolinearitas bertujuan untuk menguji apakah model regresi ditemukan adanya korelasi antar variabel bebas (independen). Model regresi yang baik seharusnya tidak terjadi korelasi di antara variabel independen. Jika variabel independen saling berkorelasi, maka variabel-variabel ini tidak ortogonal. Variabel ortogonal adalah variabel independen yang nilai korelasi antar sesama variabel independen sama dengan nol. Uji Autokorelasi, (Mappamiring \& Putra, 2021) menyatakan bahwa uji autokolerasi bertujuan untuk menguji apakah dalam model regresi linier ada korelasi antara kesalahan pengganggu pada periode-t dengan kesalahan pengganggu pada periode $\mathrm{t}-1$ (sebelumnya). Model regresi yang baik adalah model regresi yang bebas dari autokorelasi. Uji Heteroskedastisitas, menurut (Agustina et al., 2020), tujuan dari pengujian ini adalah untuk menguji apakah dalam model regresi terjadi ketidak samaan variance dari residual satu pengamatan ke pengamatan lainnya. Model regresi yang baik adalah yang homoskesdastisitas, yakni variance dari residual satu pengamatan ke pengamatan lain bersifat tetap. Menurut (Sugiyono, 2014), regresi linier berganda bermaksud meramalkan bagaimana keadaan (naik turunnya) variabel dependen, bila dua atau lebih variabel independen sebagai faktor prediktor dimanipulasi (dinaik turunkan nilainya). Jadi analisis regresi berganda akan dilakukan bila jumlah variabel independennya minimal 2". Berikut ini adalah persamaan regresi linier berganda dalam penelitian ini :

Keterangan :

$$
\mathrm{Y}=\mathrm{a}+\beta 1 \mathrm{X} 1+\beta 2 \mathrm{X} 2+\mathrm{e}
$$

$\mathrm{Y}$ = harga saham 


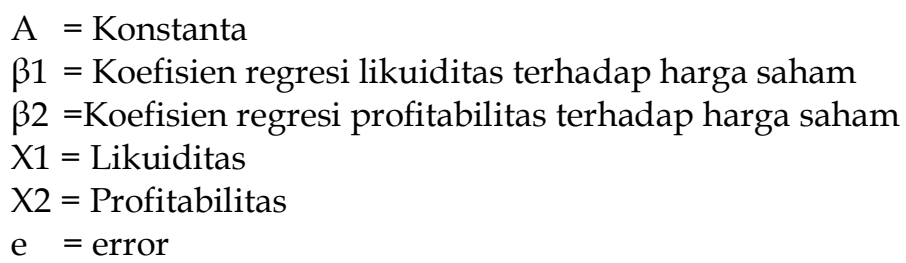

Pengujian hipotesis. Uji F, menurut (Ghozali, 2013), Uji F pada dasarnya menunjukkan apakah semua variabel independen atau bebas yang dimasukkan dalam model mempunyai pengaruh secara bersama-sama terhadap variabel dependen atau terikat. Uji-t, menurut Ghozali (2013), "Pengujian hipotesis secara parsial, dapat diuji dengan menggunakan rumus uji-t. Pengujian t-statistik bertujuan untuk menguji ada atau tidaknya pengaruh masing-masing variabel independen $(X)$ terhadap variabel dependen (Y). Uji Koefisien Determinasi (R2), menurut Ghozali (2013), koefisien determinasi digunakan untuk mengukur seberapa jauh kemampuan model yang dibentuk dalam menerangkan variasi variabel independen.

Dimana :

$$
\mathrm{KD}=\mathrm{r} 2 \times 100 \%
$$

$\mathrm{Kd}=$ Koefisien determinasi

r 2 = Kuadrat Koefisien Korelasi

Definisi Operasional dan Pengukurannya diantaranya likuiditas adalah kemampuan suatu perusahaan dalam memenuhi kewajiban jangka pendek yang dimilikinya pada saat jatuh tempo. Profitabilitas adalah rasio yang mengukur kemampuan perusahaan menghasilkan keuntungan (profitabilitas) pada tingkat penjualan, aset, dan modal saham yang tertentu. Harga saham adalah harga yang terbentuk sesuai permintaan dan penawaran dipasar jual beli saham dan biasanya merupakan harga penutupan.

\section{Hasil Penelitian dan Pembahasan}

\section{a) Hasil Penelitian}

1. Gambaran Current Ratio (CR) pada Perusahaan Sub Sektor Makanan dan Minuman yang terdaftar di Bursa Efek Indonesia (BEI) Tahun 2015-2019.

Gambaran Current Ratio (CR) pada Perusahaan Sub Sektor Makanan dan Minuman yang terdaftar di Bursa Efek Indonesia (BEI) Tahun 2015-2019 dapat dilihat pada Tabel 1 berikut ini:

Tabel 1. Gambaran Current Ratio (CR) Perusahaan Sub Sektor Makanan dan Minuman yang Terdaftar di Bursa Efek Indonesia (BEI) Tahun 2015-2019

\begin{tabular}{|c|c|c|c|c|c|}
\hline Perusahaan & Tahun & Aktiva Lancar & Utang Lancar & Current Ratio (CR) & Rata-rata CR \\
\hline \multirow{5}{*}{ ADES } & 2015 & 276.323 & 199.364 & 1,39 & \multirow{5}{*}{1,52} \\
\hline & 2016 & 319.614 & 195.466 & 1,64 & \\
\hline & 2017 & 294.244 & 244.888 & 1,20 & \\
\hline & 2018 & 364.138 & 262.397 & 1,39 & \\
\hline & 2019 & 351.120 & 175.191 & 2,00 & \\
\hline \multirow{5}{*}{ AISA } & 2015 & 4.463 .635 & 2.750 .457 & 1,62 & \multirow{5}{*}{0,95} \\
\hline & 2016 & 5.949 .164 & 2.504 .330 & 2,38 & \\
\hline & 2017 & 881.092 & 4.154 .427 & 0,21 & \\
\hline & 2018 & 788.973 & 5.177 .830 & 0,15 & \\
\hline & 2019 & 474.261 & 1.152 .923 & 0,41 & \\
\hline \multirow{5}{*}{ CEKA } & 2015 & 1.253 .019 & 816.471 & 1,53 & \multirow{5}{*}{3,17} \\
\hline & 2016 & 1.103 .865 & 504.208 & 2,19 & \\
\hline & 2017 & 988.479 & 444.383 & 2,22 & \\
\hline & 2018 & 809.166 & 158.255 & 5,11 & \\
\hline & 2019 & 1.067 .652 & 222.440 & 4,80 & \\
\hline \multirow{2}{*}{ DLTA } & 2015 & 902.007 & 140.419 & 6,42 & \multirow{2}{*}{7,58} \\
\hline & 2016 & 1.048 .133 & 137.842 & 7,60 & \\
\hline
\end{tabular}




\begin{tabular}{|c|c|c|c|c|c|}
\hline Perusahaan & Tahun & Aktiva Lancar & Utang Lancar & Current Ratio (CR) & Rata-rata CR \\
\hline \multirow{8}{*}{ ICBP } & 2017 & 1.206 .576 & 139.684 & 8,64 & \multirow{8}{*}{2,33} \\
\hline & 2018 & 1.384 .227 & 192.299 & 7,20 & \\
\hline & 2019 & 1.292 .805 & 160.587 & 8,05 & \\
\hline & 2015 & 13.961 .500 & 6.002 .344 & 2,33 & \\
\hline & 2016 & 15.571 .362 & 6.469 .785 & 2,41 & \\
\hline & 2017 & 16.579 .331 & 6.827 .588 & 2,43 & \\
\hline & 2018 & 14.121 .568 & 7.235 .398 & 1,95 & \\
\hline & 2019 & 16.624 .925 & 6.556 .359 & 2,54 & \\
\hline \multirow{5}{*}{ MYOR } & 2015 & 7.454 .347 & 3.151 .495 & 2,37 & \multirow{5}{*}{2,62} \\
\hline & 2016 & 8.739 .782 & 3.884 .051 & 2,25 & \\
\hline & 2017 & 10.674 .199 & 4.473 .628 & 2,39 & \\
\hline & 2018 & 12.647 .858 & 4.764 .510 & 2,65 & \\
\hline & 2019 & 12.776 .102 & 3.726 .359 & 3,43 & \\
\hline \multirow{5}{*}{ ROTI } & 2015 & 812.990 & 395.920 & 2,05 & \multirow{5}{*}{2,18} \\
\hline & 2016 & 949.414 & 320.502 & 2,96 & \\
\hline & 2017 & 2.319 .937 & 1.027 .176 & 2,26 & \\
\hline & 2018 & 1.876 .409 & 525.422 & 3,57 & \\
\hline & 2019 & 1.874 .411 & 52.125 .550 & 0,04 & \\
\hline \multirow{5}{*}{ ULTJ } & 2015 & 2.103 .565 & 561.628 & 3,75 & \multirow{5}{*}{4,32} \\
\hline & 2016 & 2.874 .822 & 593.526 & 4,84 & \\
\hline & 2017 & 3.439 .990 & 820.625 & 4,19 & \\
\hline & 2018 & 2.793 .521 & 635.161 & 4,40 & \\
\hline & 2019 & 3.716 .641 & 836.314 & 4,44 & \\
\hline \multirow{5}{*}{ INDF } & 2015 & 42.816 .745 & 25.107 .538 & 1,71 & \multirow{5}{*}{1,38} \\
\hline & 2016 & 28.985 .443 & 19.219 .441 & 1,51 & \\
\hline & 2017 & 32.515 .399 & 21.637 .763 & 1,50 & \\
\hline & 2018 & 33.272 .618 & 31.204 .102 & 1,07 & \\
\hline & 2019 & 33.009 .190 & 29.845 .158 & 1,11 & \\
\hline \multirow{5}{*}{ MLBI } & 2015 & 709.955 & 1.215 .227 & 0,58 & \multirow{5}{*}{0,71} \\
\hline & 2016 & 901.258 & 1.326 .261 & 0,68 & \\
\hline & 2017 & 1.076 .450 & 1.304 .114 & 0,83 & \\
\hline & 2018 & 1.228 .961 & 1.578 .919 & 0,78 & \\
\hline & 2019 & 1.068 .532 & 1.588 .693 & 0,67 & \\
\hline \multirow{5}{*}{ SKBM } & 2015 & 334.920 & 298.417 & 1,12 & \multirow{5}{*}{1,32} \\
\hline & 2016 & 519.270 & 468.980 & 1,11 & \\
\hline & 2017 & 836.639 & 511.596 & 1,64 & \\
\hline & 2018 & 851.410 & 615.507 & 1,38 & \\
\hline & 2019 & 889.743 & 668.931 & 1,33 & \\
\hline \multirow{5}{*}{ SKLT } & 2015 & 189.759 & 159.132 & 1,19 & \multirow{5}{*}{1,26} \\
\hline & 2016 & 222.687 & 169.302 & 1,32 & \\
\hline & 2017 & 267.129 & 211.493 & 1,26 & \\
\hline & 2018 & 356.735 & 291.349 & 1,22 & \\
\hline & 2019 & 378.352 & 293.281 & 1,29 & \\
\hline \multirow{5}{*}{ STTP } & 2015 & 659.691 & 554.491 & 1,19 & \multirow{5}{*}{2,03} \\
\hline & 2016 & 921.134 & 556.752 & 1,65 & \\
\hline & 2017 & 940.212 & 358.963 & 2,62 & \\
\hline & 2018 & 1.250 .807 & 676.673 & 1,85 & \\
\hline & 2019 & 1.165 .406 & 408.490 & 2,85 & \\
\hline
\end{tabular}

Sumber : Hasil Olah Data 2021

Berdasarkan Tabel 1 di atas tampak keadaan rata-rata Current Ratio (CR) perusahaan Sub Sektor Makanan dan Minuman yang terdaftar di Bursa Efek Indonesia Tahun 2015-2019, Current Ratio (CR) dengan rata-rata tertinggi yaitu sebesar 7,58 terdapat pada perusahaan PT Delta Djakarta Tbk (DLTA) dan Current Ratio (CR) dengan rata-rata terendah yaitu sebesar 0,71 terdapat pada perusahaan PT Multi Bintang Indonesia Tbk. Besar atau kecilnya Current Ratio (CR) dipengaruhi oleh besar atau kecilnya jumlah aset lancar suatu perusahaan dari pada utang lancar perusahaan yang digunakan dalam memenuhi seluruh kewajibannya dalam periode tersebut.

2. Gambaran Earning Per Share (EPS) pada Perusahaan Sub Sektor Makanan dan Minuman yang terdaftar di Bursa Efek Indonesia (BEI) Tahun 2015-2019. 
Gambaran Earning Per Share (EPS) pada Perusahaan Sub Sektor Makanan dan Minuman yang terdaftar di Bursa Efek Indonesia (BEI) Tahun 2015-2019 dapat dilihat pada Tabel 2 berikut ini:

Tabel 2. Gambaran Earning Per Share (EPS) Perusahaan Sub Sektor Makanan dan Minuman yang Terdaftar di Bursa Efek Indonesia (BEI) Tahun 2015-2019

\begin{tabular}{|c|c|c|c|c|c|}
\hline Perusahaan & Tahun & $\begin{array}{c}\text { Laba setelah pajak (EAT) } \\
\text { Dalam juta rupiah }\end{array}$ & $\begin{array}{l}\text { Jumlah Saham } \\
\text { Yang Beredar }\end{array}$ & $\begin{array}{l}\text { Earning Per Share } \\
\text { (EPS) }\end{array}$ & Rata-rata EPS \\
\hline \multirow{5}{*}{ ADES } & 2015 & 32.839 & 589.897 & 0,06 & \multirow{5}{*}{0,09} \\
\hline & 2016 & 55.951 & 589.897 & 0,09 & \\
\hline & 2017 & 38.242 & 589.897 & 0,06 & \\
\hline & 2018 & 52.958 & 589.897 & 0,09 & \\
\hline & 2019 & 83.885 & 589.897 & 0,14 & \\
\hline \multirow{5}{*}{ AISA } & 2015 & 373750 & 3.218 .600 & 0,12 & \multirow{5}{*}{0,47} \\
\hline & 2016 & 719.228 & 3.218 .600 & 0,22 & \\
\hline & 2017 & 5.234 .288 & 3.218 .600 & 1,63 & \\
\hline & 2018 & 123.513 & 3.218 .600 & 0,04 & \\
\hline & 2019 & 1.134 .776 & 3.218 .600 & 0,35 & \\
\hline \multirow{5}{*}{ CEKA } & 2015 & 106.549 & 595.000 & 0,18 & \multirow{5}{*}{31,37} \\
\hline & 2016 & 249.697 & 595.000 & 0,42 & \\
\hline & 2017 & 107.420 & 595.000 & 0,18 & \\
\hline & 2018 & 92.649 .656 & 595.000 & 155,71 & \\
\hline & 2019 & 215.459 & 595.000 & 0,36 & \\
\hline \multirow{5}{*}{ DLTA } & 2015 & 192.045 & 800.659 & 0,24 & \multirow{5}{*}{0,35} \\
\hline & 2016 & 254.509 & 800.659 & 0,32 & \\
\hline & 2017 & 279.772 & 800.659 & 0,35 & \\
\hline & 2018 & 338.129 & 800.659 & 0,42 & \\
\hline & 2019 & 317.815 & 800.659 & 0,40 & \\
\hline \multirow{5}{*}{ ICBP } & 2015 & 3.025 .095 & 11.661 .908 & 0,02 & \multirow{5}{*}{0,30} \\
\hline & 2016 & 3.631 .301 & 11.661 .908 & 0,31 & \\
\hline & 2017 & 3.543 .173 & 11.661 .908 & 0,30 & \\
\hline & 2018 & 4.658 .781 & 11.661 .908 & 0,40 & \\
\hline & 2019 & 5.360 .029 & 11.661 .908 & 0,46 & \\
\hline \multirow{5}{*}{ MYOR } & 2015 & 1.266 .519 & 22.358 .699 & 0,06 & \multirow{5}{*}{0,07} \\
\hline & 2016 & 1.345 .716 & 22.358 .699 & 0,06 & \\
\hline & 2017 & 1.570 .140 & 22.358 .699 & 0,07 & \\
\hline & 2018 & 1.760 .434 & 22.358 .699 & 0,08 & \\
\hline & 2019 & 2.039 .404 & 22.358 .699 & 0,09 & \\
\hline \multirow{5}{*}{ ROTI } & 2015 & 263.710 & 6.186 .488 & 0,04 & \multirow{5}{*}{0,03} \\
\hline & 2016 & 263.392 & 6.186 .488 & 0,04 & \\
\hline & 2017 & 124.467 & 6.186 .488 & 0,02 & \\
\hline & 2018 & 136.301 & 6.186 .488 & 0,02 & \\
\hline & 2019 & 221.853 & 6.186 .488 & 0,04 & \\
\hline & 2015 & 523.100 & 11.553 .528 & 0,05 & \\
\hline & 2016 & 699.894 & 11.553 .528 & 0,06 & \\
\hline ULTJ & 2017 & 694.642 & 11.553 .528 & 0,06 & 0,06 \\
\hline & 2018 & 701.607 & 11.553 .528 & 0,06 & \\
\hline & 2019 & 1.035 .865 & 11.553 .528 & 0,09 & \\
\hline & 2015 & 3.709 .501 & 8.780 .426 & 0,42 & \\
\hline & 2016 & 5.266 .906 & 8.780 .426 & 0,60 & \\
\hline INDF & 2017 & 5.145 .063 & 8.780 .426 & 0,59 & 0,57 \\
\hline & 2018 & 4.961 .851 & 8.780 .426 & 0,57 & \\
\hline & 2019 & 5.902 .729 & 8.780 .426 & 0,67 & \\
\hline & 2015 & 496.909 & 2.107 .000 & 0,24 & 036 \\
\hline & 2016 & 982.129 & 2.107 .000 & 0,47 & 0,36 \\
\hline MLBI & 2017 & 1.322 .067 & 2.107 .000 & 0,63 & \\
\hline & 2018 & 463.878 & 2.107 .000 & 0,22 & \\
\hline & 2019 & 485.763 & 2.107 .000 & 0,23 & \\
\hline & 2015 & 40.150 .568 & 936.530 & 42,87 & \\
\hline & 2016 & 22.545 .456 & 936.530 & 24,07 & \\
\hline SKBM & 2017 & 25.880 .464 & 936.530 & 27,63 & 22,53 \\
\hline & 2018 & 15.954 .632 & 936.530 & 17,04 & \\
\hline & 2019 & 957.169 & 936.530 & 1,02 & \\
\hline & 2015 & 20.066 .792 & 690.740 & 29,05 & \\
\hline SKLT & 2016 & 20.646 .121 & 690.740 & 29,89 & 40,70 \\
\hline & 2017 & 22.970 .715 & 690.740 & 33,26 & \\
\hline
\end{tabular}




\begin{tabular}{|c|c|c|c|c|c|}
\hline \multirow{2}{*}{ Perusahaan } & \multirow{2}{*}{ Tahun } & Laba setelah pajak (EAT) & Jumlah Saham & Earning Per Share & \multirow{2}{*}{ Rata-rata EPS } \\
\hline & & Dalam juta rupiah & Yang Beredar & (EPS) & \\
\hline & 2018 & 31.954 .131 & 690.740 & 46,26 & \\
\hline & 2019 & 44.943 .628 & 690.740 & 65,07 & \\
\hline \multirow{5}{*}{ STTP } & 2015 & 185.705 & 1.310 .000 & 0,14 & \multirow{5}{*}{0,20} \\
\hline & 2016 & 174.177 & 1.310 .000 & 0,13 & \\
\hline & 2017 & 216.024 & 1.310 .000 & 0,16 & \\
\hline & 2018 & 255.089 & 1.310 .000 & 0,19 & \\
\hline & 2019 & 482.590 & 1.310 .000 & 0,37 & \\
\hline
\end{tabular}

Sumber : Hasil Olah Data 2021

Berdasarkan Tabel 2 di atas tampak keadaan rata-rata Earning Per Share (EPS) perusahaan Sub Sektor Makanan dan Minuman yang terdaftar di Bursa Efek Indonesia Tahun 2015-2019, Earning Per Share (EPS) dengan rata-rata tertinggi yaitu sebesar 40,70 terdapat pada perusahaan PT Sekar Laut Tbk (SKLT) dan PT Wilmar Cahaya Indonesia (CEKA) sebesar 31,37, sedangkan Earning Per Share (EPS) dengan rata-rata terendah yaitu sebesar 0,03 terdapat pada perusahaan PT Nippon Indosari Carpindo Tbk (ROTI). Besar atau kecilnya Earning Per Share (EPS) dipengaruhi oleh besar atau kecilnya laba yang diperoleh suatu perusahaan dan jumlah saham yang beredar.

\section{Gambaran Return On Investmen (ROI) pada Perusahaan Sub Sektor Makanan dan Minuman} yang terdaftar di Bursa Efek Indonesia (BEI) Tahun 2015-2019.

Gambaran Return On Investmen (ROI) pada Perusahaan Sub Sektor Makanan dan Minuman yang terdaftar di Bursa Efek Indonesia (BEI) Tahun 2015-2019 dapat dilihat pada Tabel 3 berikut ini:

Tabel 3. Gambaran Return On Investmen (ROI) Perusahaan Sub Sektor Makanan dan Minuman yang Terdaftar di Bursa Efek Indonesia (BEI) Tahun 2015-2019

\begin{tabular}{|c|c|c|c|c|c|}
\hline Perusahaan & Tahun & $\begin{array}{l}\text { Laba setelah pajak (EAT) } \\
\text { Dalam juta rupiah }\end{array}$ & $\begin{array}{l}\text { Total Aktiva (TA) } \\
\text { Dalam Juta Rupiah }\end{array}$ & $\begin{array}{c}\text { Return On } \\
\text { Investmen (ROI) } \\
(\text { EAT/TA)*100\% }\end{array}$ & $\begin{array}{l}\text { Rata-rata } \\
\text { (ROI) }\end{array}$ \\
\hline \multirow{5}{*}{ ADES } & 2015 & 32.839 & 653.224 & 0,05 & \multirow{5}{*}{0,07} \\
\hline & 2016 & 55.951 & 767.479 & 0,07 & \\
\hline & 2017 & 38.242 & 840.236 & 0,05 & \\
\hline & 2018 & 52.958 & 881.275 & 0,06 & \\
\hline & 2019 & 83.885 & 822.375 & 0,10 & \\
\hline \multirow{5}{*}{ AISA } & 2015 & 373750 & 9.060 .979 & 0,04 & \multirow{5}{*}{0,69} \\
\hline & 2016 & 719.228 & 9.254 .539 & 0,08 & \\
\hline & 2017 & 5.234 .288 & 1.981 .940 & 2,64 & \\
\hline & 2018 & 123.513 & 1.816 .406 & 0,07 & \\
\hline & 2019 & 1.134 .776 & 1.868 .966 & 0,61 & \\
\hline \multirow{5}{*}{ CEKA } & 2015 & 106.549 & 1.485 .826 & 0,07 & \multirow{5}{*}{15,95} \\
\hline & 2016 & 249.697 & 1.425 .964 & 0,18 & \\
\hline & 2017 & 107.420 & 1.392 .636 & 0,08 & \\
\hline & 2018 & 92.649 .656 & 1.168 .956 & 79,26 & \\
\hline & 2019 & 215.459 & 1.393 .079 & 0,15 & \\
\hline \multirow{5}{*}{ DLTA } & 2015 & 192.045 & 1.038 .322 & 0,18 & \multirow{5}{*}{0,21} \\
\hline & 2016 & 254.509 & 1.197 .796 & 0,21 & \\
\hline & 2017 & 279.772 & 1.340 .842 & 0,21 & \\
\hline & 2018 & 338.129 & 1.523 .517 & 0,22 & \\
\hline & 2019 & 317.815 & 1.425 .983 & 0,22 & \\
\hline \multirow{5}{*}{ ICBP } & 2015 & 3.025 .095 & 26.560 .624 & 0,11 & \multirow{5}{*}{0,12} \\
\hline & 2016 & 3.631 .301 & 28.901 .948 & 0,13 & \\
\hline & 2017 & 3.543 .173 & 31.619 .514 & 0,11 & \\
\hline & 2018 & 4.658 .781 & 34.367 .153 & 0,14 & \\
\hline & 2019 & 5.360 .029 & 38.709 .314 & 0,14 & \\
\hline \multirow{5}{*}{ MYOR } & 2015 & 1.266 .519 & 11.342 .715 & 0,11 & \multirow{5}{*}{0,11} \\
\hline & 2016 & 1.345 .716 & 12.922 .422 & 0,10 & \\
\hline & 2017 & 1.570 .140 & 14.915 .849 & 0,11 & \\
\hline & 2018 & 1.760 .434 & 17.591.706 & 0,10 & \\
\hline & 2019 & 2.039 .404 & 19.037 .918 & 0,11 & \\
\hline ROTI & 2015 & 263.710 & 2.706 .323 & 0,10 & 0,06 \\
\hline
\end{tabular}




\begin{tabular}{|c|c|c|c|c|c|}
\hline Perusahaan & Tahun & $\begin{array}{l}\text { Laba setelah pajak (EAT) } \\
\text { Dalam juta rupiah }\end{array}$ & $\begin{array}{l}\text { Total Aktiva (TA) } \\
\text { Dalam Juta Rupiah }\end{array}$ & $\begin{array}{c}\text { Return On } \\
\text { Investmen (ROI) } \\
\text { (EAT/TA)*100\% }\end{array}$ & $\begin{array}{c}\text { Rata-rata } \\
\text { (ROI) }\end{array}$ \\
\hline & 2016 & 263.392 & 2.919 .641 & 0,09 & \\
\hline & 2017 & 124.467 & 4.559 .573 & 0,03 & \\
\hline & 2018 & 136.301 & 4.393 .810 & 0,03 & \\
\hline & 2019 & 221.853 & 4.682 .083 & 0,05 & \\
\hline \multirow{5}{*}{ ULTJ } & 2015 & 523.100 & 3.539 .996 & 0,15 & \multirow{5}{*}{0,15} \\
\hline & 2016 & 699.894 & 4.239 .200 & 0,17 & \\
\hline & 2017 & 694.642 & 5.186 .940 & 0,13 & \\
\hline & 2018 & 701.607 & 5.555 .871 & 0,13 & \\
\hline & 2019 & 1.035 .865 & 6.608 .422 & 0,16 & \\
\hline \multirow{5}{*}{ INDF } & 2015 & 3.709 .501 & 91.831 .526 & 0,04 & \multirow{5}{*}{0,06} \\
\hline & 2016 & 5.266 .906 & 82.174 .515 & 0,06 & \\
\hline & 2017 & 5.145 .063 & 87.939 .488 & 0,06 & \\
\hline & 2018 & 4.961 .851 & 96.537 .796 & 0,05 & \\
\hline & 2019 & 5.902 .729 & 97.367 .672 & 0,06 & \\
\hline \multirow{5}{*}{ MLBI } & 2015 & 496.909 & 2.100 .853 & 0,24 & \multirow{5}{*}{0,31} \\
\hline & 2016 & 982.129 & 2.275 .038 & 0,43 & \\
\hline & 2017 & 1.322 .067 & 2.510 .078 & 0,53 & \\
\hline & 2018 & 463.878 & 2.889 .501 & 0,16 & \\
\hline & 2019 & 485.763 & 2.804 .869 & 0,17 & \\
\hline \multirow{5}{*}{ SKBM } & 2015 & 40.150 .568 & 764.484 & 52,52 & \multirow{5}{*}{20,10} \\
\hline & 2016 & 22.545 .456 & 1.001 .657 & 22,51 & \\
\hline & 2017 & 25.880 .464 & 1.623 .027 & 15,95 & \\
\hline & 2018 & 15.954 .632 & 1.771 .366 & 9,01 & \\
\hline & 2019 & 957.169 & 1.820 .383 & 0,53 & \\
\hline \multirow{5}{*}{ SKLT } & 2015 & 20.066 .792 & 377.110 & 53,21 & \multirow{5}{*}{45,05} \\
\hline & 2016 & 20.646 .121 & 568.240 & 36,33 & \\
\hline & 2017 & 22.970 .715 & 636.284 & 36,10 & \\
\hline & 2018 & 31.954 .131 & 747.294 & 42,76 & \\
\hline & 2019 & 44.943 .628 & 790.845 & 56,83 & \\
\hline \multirow{5}{*}{ STTP } & 2015 & 185.705 & 1.919 .568 & 0,10 & \multirow{5}{*}{0,11} \\
\hline & 2016 & 174.177 & 2.336 .411 & 0,07 & \\
\hline & 2017 & 216.024 & 2.342 .432 & 0,09 & \\
\hline & 2018 & 255.089 & 2.631 .190 & 0,10 & \\
\hline & 2019 & 482.590 & 2.881 .563 & 0,17 & \\
\hline
\end{tabular}

Sumber : Hasil Olah Data 2021

Berdasarkan Tabel di atas tampak keadaan rata-rata Return On Investmen (ROI) perusahaan Sub Sektor Makanan dan Minuman yang terdaftar di Bursa Efek Indonesia Tahun 2015-2019, Return On Investmen (ROI) dengan rata-rata tertinggi yaitu sebesar 45,05 terdapat pada perusahaan PT Sekar Laut Tbk (SKLT) sedangkan Return On Investmen (ROI) dengan rata-rata terendah yaitu sebesar 0,06 terdapat pada perusahaan PT Nippon Indosari Carpindo Tbk (ROTI) dan PT Indofood Sukses Makmur Tbk (INDF). Besar atau kecilnya Return On Investmen (ROI) dipengaruhi oleh besar atau kecilnya laba yang diperoleh suatu perusahaan dan total aktiva sebuah perusahaan.

\section{Gambaran Retun Of Ekuity (ROE) pada Perusahaan Sub Sektor Makanan dan Minuman yang terdaftar di Bursa Efek Indonesia (BEI) Tahun 2015-2019.}

Gambaran Retun Of Ekuity (ROE) pada Perusahaan Sub Sektor Makanan dan Minuman yang terdaftar di Bursa Efek Indonesia (BEI) Tahun 2015-2019 dapat dilihat pada Tabel 4 berikut ini:

Tabel 4. Gambaran Retun Of Ekuity (ROE) Perusahaan Sub Sektor Makanan dan Minuman yang Terdaftar di Bursa Efek Indonesia (BEI) Tahun 2015-2019

\begin{tabular}{|c|c|c|c|c|c|}
\hline \multirow{3}{*}{ Perusahaan } & Tahun & $\begin{array}{c}\text { Laba setelah pajak } \\
\text { (EAT) } \\
\text { Dalam juta rupiah }\end{array}$ & $\begin{array}{c}\text { Total ekuitas (TE) } \\
\text { Dalam Juta Rupiah }\end{array}$ & $\begin{array}{c}\text { Retun of } \text { ekuity } \\
\text { (ROE) } \\
\text { (EAT/TE) }\end{array}$ & \multirow{2}{*}{ Rata-rata (ROE) } \\
\hline \multirow{3}{*}{ ADES } & 2015 & 32.839 & 328.369 & 0,10 & \multirow{2}{*}{0,12} \\
\cline { 2 - 5 } & 2016 & 55.951 & 384.388 & 0,15 & \\
\cline { 2 - 5 } & 2017 & 38.242 & 432.011 & 0,09 & 0,11 \\
\cline { 2 - 5 } & 2018 & 52.958 & 481.914 & & \\
\hline
\end{tabular}




\begin{tabular}{|c|c|c|c|c|c|}
\hline & 2019 & 83.885 & 567.937 & 0,15 & \\
\hline \multirow{5}{*}{ AISA } & 2015 & 373750 & 3.966 .907 & 0,09 & \multirow{5}{*}{0,51} \\
\hline & 2016 & 719.228 & 4.264 .400 & 0,17 & \\
\hline & 2017 & 5.234 .288 & 3.347 .901 & 1,56 & \\
\hline & 2018 & 123.513 & 3.450 .942 & 0,04 & \\
\hline & 2019 & 1.134 .776 & 1.657 .853 & 0,68 & \\
\hline \multirow{5}{*}{ CEKA } & 2015 & 106.549 & 639.893 & 0,17 & \multirow{5}{*}{19,12} \\
\hline & 2016 & 249.697 & 887.920 & 0,28 & \\
\hline & 2017 & 107.420 & 903.044 & 0,12 & \\
\hline & 2018 & 92.649 .656 & 976.647 & 94,87 & \\
\hline & 2019 & 215.459 & 1.131 .294 & 0,19 & \\
\hline \multirow{5}{*}{ DLTA } & 2015 & 192.045 & 849.621 & 0,23 & \multirow{5}{*}{0,25} \\
\hline & 2016 & 254.509 & 1.012 .374 & 0,25 & \\
\hline & 2017 & 279.772 & 1.144 .645 & 0,24 & \\
\hline & 2018 & 338.129 & 1.284 .164 & 0,26 & \\
\hline & 2019 & 317.815 & 1.213 .563 & 0,26 & \\
\hline \multirow{5}{*}{ ICBP } & 2015 & 3.025 .095 & 16.386.911 & 0,18 & \multirow{5}{*}{0,16} \\
\hline & 2016 & 3.631.301 & 28.901 .948 & 0,13 & \\
\hline & 2017 & 3.543 .173 & 31.619 .514 & 0,11 & \\
\hline & 2018 & 4.658 .781 & 22.707 .150 & 0,21 & \\
\hline & 2019 & 5.360 .029 & 26.671 .104 & 0,20 & \\
\hline \multirow{5}{*}{ MYOR } & 2015 & 1.266 .519 & 5.194 .459 & 0,24 & \multirow{5}{*}{0,22} \\
\hline & 2016 & 1.345 .716 & 6.265 .256 & 0,21 & \\
\hline & 2017 & 1.570 .140 & 7.354.346 & 0,21 & \\
\hline & 2018 & 1.760 .434 & 8.542 .544 & 0,21 & \\
\hline & 2019 & 2.039 .404 & 9.899 .940 & 0,21 & \\
\hline \multirow{5}{*}{ ROTI } & 2015 & 263.710 & 1.188 .535 & 0,22 & \multirow{5}{*}{0,11} \\
\hline & 2016 & 263.392 & 1.442 .755 & 0,18 & \\
\hline & 2017 & 124.467 & 2.820 .105 & 0,04 & \\
\hline & 2018 & 136.301 & 2.916 .901 & 0,05 & \\
\hline & 2019 & 221.853 & 3.092 .597 & 0,07 & \\
\hline \multirow{5}{*}{ ULTJ } & 2015 & 523.100 & 2.797 .505 & 0,19 & \multirow{5}{*}{0,18} \\
\hline & 2016 & 699.894 & 3.489 .233 & 0,20 & \\
\hline & 2017 & 694.642 & 4.208 .755 & 0,17 & \\
\hline & 2018 & 701.607 & 4.774 .956 & 0,15 & \\
\hline & 2019 & 1.035 .865 & 5.655 .139 & 0,18 & \\
\hline \multirow{5}{*}{ INDF } & 2015 & 3.709 .501 & 43.121 .593 & 0,09 & \multirow{5}{*}{0,11} \\
\hline & 2016 & 5.266 .906 & 43.941 .423 & 0,12 & \\
\hline & 2017 & 5.145 .063 & 46.756.724 & 0,11 & \\
\hline & 2018 & 4.961 .851 & 49.916 .800 & 0,10 & \\
\hline & 2019 & 5.902 .729 & 51.248 .190 & 0,12 & \\
\hline & 2015 & 496.909 & 766.480 & 0,65 & \\
\hline & 2016 & 982.129 & 820.640 & 1,20 & \\
\hline MLBI & 2017 & 1.322 .067 & 1.064 .905 & 1,24 & 0,88 \\
\hline & 2018 & 463.878 & 1.167 .536 & 0,40 & \\
\hline & 2019 & 485.763 & 523.825 & 0,93 & \\
\hline & 2015 & 40.150 .568 & 344.087 & 116,69 & \\
\hline & 2016 & 22.545 .456 & 368.389 & 61,20 & \\
\hline SKBM & 2017 & 25.880 .464 & 1.023 .237 & 25,29 & 43,89 \\
\hline & 2018 & 15.954 .632 & 1.040 .576 & 15,33 & \\
\hline & 2019 & 957.169 & 1.035 .820 & 0,92 & \\
\hline & 2015 & 20.066 .792 & 152.044 & 131,98 & \\
\hline & 2016 & 20.646 .121 & 296.151 & 69,71 & \\
\hline SKLT & 2017 & 22.970 .715 & 307.569 & 74,68 & 97,75 \\
\hline & 2018 & 31.954 .131 & 339.236 & 94,19 & \\
\hline & 2019 & 44.943 .628 & 380.382 & 118,15 & \\
\hline & 2015 & 185.705 & 1.008 .809 & 0,18 & \\
\hline & 2016 & 174.177 & 1.168 .512 & 0,15 & \\
\hline STTP & 2017 & 216.024 & 1.384 .772 & 0,16 & 0,17 \\
\hline & 2018 & 255.089 & 1.646 .388 & 0,15 & \\
\hline & 2019 & 482.590 & 2.148 .007 & 0,22 & \\
\hline
\end{tabular}

Berdasarkan Tabel 4 di atas tampak keadaan rata-rata Retun Of Ekuity (ROE) perusahaan Sub Sektor Makanan dan Minuman yang terdaftar di Bursa Efek Indonesia Tahun 2015-2019, Retun Of Ekuity (ROE) dengan rata-rata tertinggi yaitu sebesar 97,75 terdapat pada perusahaan PT Sekar Laut 
Tbk (SKLT) sedangkan Retun Of Ekuity (ROE) dengan rata-rata terendah yaitu sebesar 0,11 terdapat pada perusahaan PT Nippon Indosari Carpindo Tbk (ROTI) dan PT Indofood Sukses Makmur Tbk (INDF). Besar atau kecilnya Return On Investmen (ROI) dipengaruhi oleh besar atau kecilnya laba yang diperoleh suatu perusahaan dan total ekuitas sebuah perusahaan.

\section{Hasil Uji Statistik Deskriptif}

Tabel 5. Deskriptif Statistik

\begin{tabular}{|c|r|r|r|r|r|}
\hline & $\mathrm{N}$ & \multicolumn{1}{|c|}{ Minimum } & \multicolumn{1}{c|}{ Maximum } & \multicolumn{1}{c|}{ Mean } & \multicolumn{1}{c|}{ Std. Deviation } \\
\hline Harga Saham & 65 & 168 & 30500 & 4327,23 & 5216,495 \\
\hline CR & 65 &, 035959543832151 & 8,637896967440795 & 2,413219830263906 & 1,906891805896385 \\
\hline EPS & 65 &, 018055555555556 & 155,713707563025220 & 7,469282322194680 & 22,816140299194150 \\
\hline ROI & 65 &, 027297950926545 & 79,258463107251260 & 6,381565214592265 & 16,656926685641647 \\
\hline ROE & 65 &, 035791097039591 & 131,980163636841980 & 12,574470171213022 & 32,513747734042260 \\
\hline Valid N (listwise) & 65 & & & & \\
\hline
\end{tabular}

Sumber: Data diolah menggunakan SPSS-25

Berdasarkan hasil olah data pada tabel 5, terlihat bahwa dari 13 perusaaan dengan 65 pengamatan, variabel Current Ratio (CR) selama lima tahun (2015-2019) memiliki nilai Minimum sebesar 0,035959543832151 dan nilai Maximum sebesar 8,637896967440795 dengan nilai rata-rata (Mean) sebesar 2,413219830263906 atau 241,3\% secara rata-rata masuk dalam kategori baik berdasarkan standar industri yang ditetapkan sebesar 200\% dan nilai standar deviasi sebesar 1,906891805896385. Variabel Earning Per Share (EPS) selama tahun 2015-2019 memiliki nilai Minimum sebesar 0,0180555555555556 dan nilai Maximum sebesar 155,713707563025220 dengan nilai rata-rata (Mean) sebesar 7,469282322194680 atau $746,9 \%$ secara rata-rata masuk dalam kategori baik berdasarkan standar industri yang ditetapkan sebesar 200\% dan nilai standar deviasi sebesar 22,816140299194150. Variabel Return Of Investmen (ROI) selama tahun 2015-2019 memiliki nilai Minimum sebesar 0,027297950926545 dan nilai Maximum sebesar 79,258463107251260 dengan nilai rata-rata (Mean) sebesar 6,381565214592265 atau 638,1\% secara rata-rata masuk dalam kategori baik berdasarkan standar industri yang ditetapkan sebesar $200 \%$ dan nilai standar deviasi sebesar 16,656926685641647. Variabel Return Of Ekuity (ROE) selama tahun 2015-2019 memiliki nilai Minimum sebesar 0,035791097039591 dan nilai Maximum sebesar 131,980163636841980 dengan nilai ratarata (Mean) sebesar 12,574470171213022 atau 125,7\% secara rata-rata masuk dalam kategori kurang baik berdasarkan standar industri yang ditetapkan sebesar 200\% dan nilai standar deviasi sebesar 32,513747734042260. Uji Asumsi Klasik digunakan untuk menguji, apakah model regresi yang digunakan dalam penelitian ini layak diuji atau tidak. Uji Asumsi klasik digunakan untuk memastikan bahwa multikolinearitas, autokorelasi, dan heteroskedastisitas tidak terdapat dalam model yang digunakan dan data yang dihasilkan terdistribusi normal. Jika keseluruhan syarat tersebut terpenuhi, berarti bahwa model analisis telah layak digunakan. Uji penyimpangan asumsi klasik, dapat dijabarkan sebagai berikut.

\section{a. Uji Normalitas}




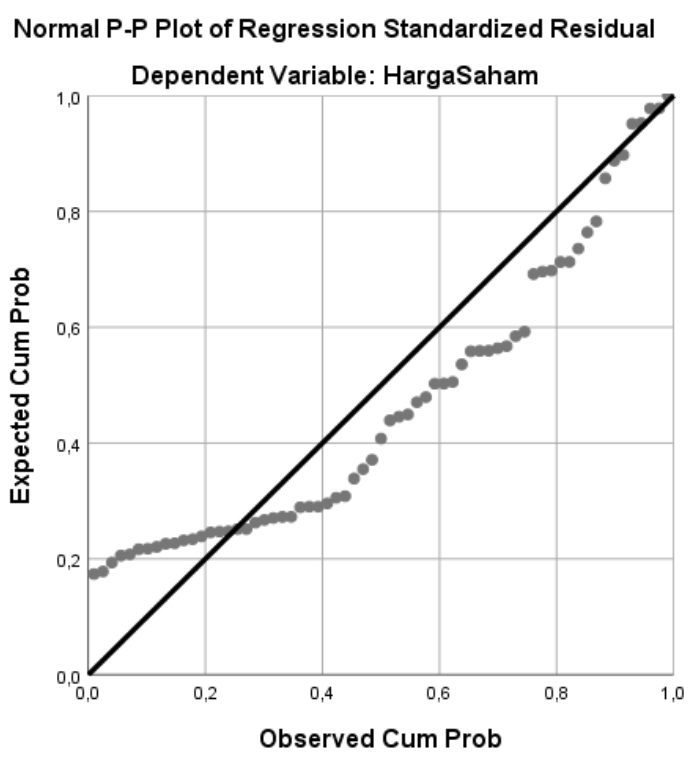

Gambar 2. Hasil Uji Normalitas Probability Plot

Grafik Normal P-Plot pada gambar di atas juga terlihat bahwa titik-titik itu tidak mengikuti garis diagonal. Hal ini menunjukkan bahwa grafik menunjukkan pola distribusi tidak normal. Maka model regresi tidak memenuhi asumsi normalitas.

\begin{tabular}{|c|c|c|}
\hline \multicolumn{3}{|c|}{ One-Sample Kolmogorov-Smirnov Test } \\
\hline \multirow{2}{*}{\multicolumn{2}{|c|}{ 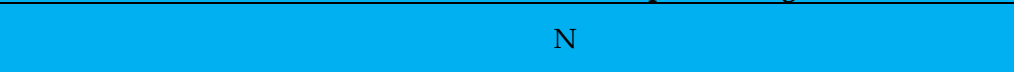 }} & Unstandardized Residual \\
\hline & & 65 \\
\hline \multirow{2}{*}{ Normal Parameters ${ }^{\mathrm{a}, \mathrm{b}}$} & Mean & ,0000000 \\
\hline & Std. Deviation & 5053,11430288 \\
\hline \multirow{3}{*}{ Most Extreme Differences } & Absolute & 166 \\
\hline & Positive & ,159 \\
\hline & Negative &,- 166 \\
\hline \multicolumn{2}{|l|}{ Test Statistic } & 166 \\
\hline \multicolumn{2}{|l|}{ Asymp. Sig. (2-tailed) } & , $000^{c}$ \\
\hline \multicolumn{3}{|l|}{ a. Test distribution is Normal. } \\
\hline \multicolumn{3}{|l|}{ b. Calculated from data. } \\
\hline \multicolumn{3}{|l|}{ c. Lilliefors Significance Correction. } \\
\hline
\end{tabular}

Sumber : Hasil Olah Data 2021

Uji Normalitas Kolmogorov-Smirnov pada tabel di atas dengan Asymp. Sig. sebesar 0,000 < 0,05. Hal ini menunjukkan bahwa tabel Kolmogorov-Smirnov menunjukkan pola distribusi tidak normal. Maka model regresi tidak memenuhi asumsi normalitas. Pada tabel di 7 terlihat bahwa nilai tolerance pada variabel likuiditas (CR) sebesar 0,933 > 0,10 yang artinya tidak terjadi gejala multikolinearitas (Ghozali, 2001). Variabel profitabilitas (EPS, ROI, ROE), terlihat bahwa nilai tolerance pada variabel EPS sebesar 0,019 $<0,10$ yang artinya terjadi gejala multikolinearitas, dan untuk variabel ROI terlihat bahwa nilai tolerance sebesar $0,003<0,10$ artinya terjadi gejala multikolinearitas, sedangkan untuk variabel ROE terlihat bahwa nilai tolerance sebesar 0,008 yang artinya terjadi gejala multikolinearitas. Sedangkan nilai VIF pada variabel likuiditas (CR) sebesar 1,072 $<10$ yang artinya tidak terjadi gejala multikolinearitas, sedangkan variabel profitabilitas (EPS, ROI, $\mathrm{ROE}$ ) lebih besar dari 10, yang artinya terjadi gejala multikolinearitas. Maka dapat disimpulkan pada model regresi yang terbentuk terjadi gejala multikolinearitas.

\section{b. Uji Multikolinearitas}

Tabel 7. Uji Multikolinearitas

\begin{tabular}{|l|c|c|}
\hline \multicolumn{4}{|c|}{ Coefficients $^{\mathbf{a}}$} \\
\hline \multirow{3}{*}{ Model } & Collinearity Statistics \\
\cline { 2 - 3 } & Tolerance & VIF \\
\hline
\end{tabular}




\begin{tabular}{|l|l|r|r|}
\hline \multirow{1}{*}{1} & (Constant) &, 933 & 1,072 \\
\cline { 2 - 4 } & CR &, 019 & 52,745 \\
\cline { 2 - 4 } & EPS &, 003 & 290,272 \\
\cline { 2 - 4 } & ROI &, 008 & 122,448 \\
\cline { 2 - 4 } & ROE & \multicolumn{3}{|c|}{} \\
\hline
\end{tabular}

Sumber : Hasil Olah Data 2021

\section{c. Uji Heteroskedastisitas}

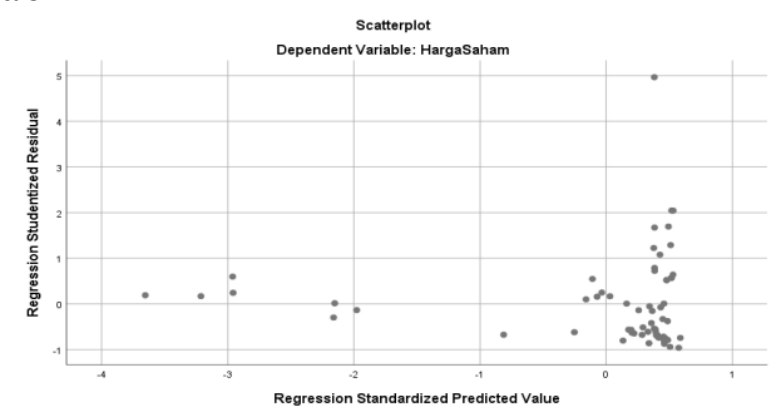

Gambar 3. Uji Heteroskedastisitas

Pada gambar 3 di atas terlihat bahwa titik-titik itu menyebar diatas dan di bawah angka 0 . Jadi, dapat disimpulkan bahwa model regresi yang digunakan tidak terdapat adanya heteroskedastisitas.

Tabel 8. Uji Heteroskedastisitas dengan Glesjer

\begin{tabular}{|c|c|c|}
\hline \multicolumn{2}{|c|}{ Model } & Sig \\
\hline \multirow[t]{5}{*}{1} & (Constant) & ,000 \\
\hline & $\mathrm{CR}$ & ,019 \\
\hline & EPS & ,833 \\
\hline & ROI & 897 \\
\hline & ROE & 885 \\
\hline
\end{tabular}

Sumber : Hasil Olah Data 2021

Hasil uji heteroskedastisitas dengan menggunakan uji Glejser pada tabel 8 menunjukkan nilai probabilitas signifikansi CR, EPS, ROI, dan ROE diatas 0,05. Jadi, dapat disimpulkan bahwa model regresi yang digunakan tidak terdapat adanya heteroskedastisitas.

\section{d. Uji Autokorelasi}

\section{Tabel 9. Uji Durbin-Watson}

\begin{tabular}{|l|r|r|r|r|r|}
\hline & Rodel & R Square & Adjusted R Square & $\begin{array}{c}\text { Std. Error of the } \\
\text { Estimate }\end{array}$ & Durbin-Watson \\
\hline $\begin{array}{l}\text { 1 } \\
\text { a. Predictors: (Constant), ROE, CR, EPS, ROI }\end{array}$ &,- 001 & 5218,834 &, 939 \\
\hline
\end{tabular}

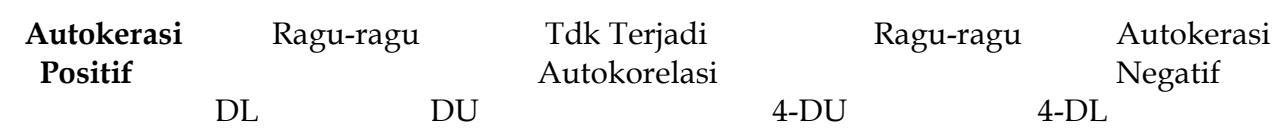

\begin{tabular}{|ccccc|}
\hline $\mid$ & $\mid$ & $\mid$ & $\mid$ & \\
0 & $\mathbf{0 , 9 3 9} 1,4709$ & 1,7311 & 2,2689 & 2,5291
\end{tabular}

Grafik 1. Uji Tabel Durbin-Watson 
Berdasarkan tabel tersebut diketahui bahwa nilai Durbin Watson sebesar 0,939 yang artinya $1.4709 \mathrm{dL}>0,939<1.7311 \mathrm{dU}$. Maka dapat disimpulkan bahwa terdapat autokorelasi pada data yang digunakan pada penelitian ini.

\section{Uji Analisis Regresi Linier Berganda}

Tabel 10. Regresi Linear Berganda

\begin{tabular}{|l|l|r|r|r|}
\hline \multirow{2}{*}{ Model } & \multicolumn{2}{|c|}{ Unstandardized Coefficients } & \multicolumn{1}{c|}{ Standardized Coefficients } \\
\cline { 3 - 5 } & (Constant) & B & Std. Error & \multicolumn{1}{c|}{ Beta } \\
\cline { 2 - 5 } & CR & 5096,456 & 1127,517 &,- 041 \\
\cline { 2 - 5 } & EPS & $-111,543$ & 354,261 &,- 473 \\
\cline { 2 - 5 } & ROI & 44,060 & 207,649 &, 061 \\
\cline { 2 - 5 } & ROE & $-149,140$ & 667,254 & 222,020 \\
\hline
\end{tabular}

a. Dependent Variable: HargaSaham

Sumber : Hasil Olah Data 2021

Berdasarkan Hasil regresi linier berganda dapat dimasukkan dalam persamaan menjadi :

$$
\mathrm{Y}=5096,456-111,543 \mathrm{X} 1+44,060 \mathrm{X} 2-149,140 \mathrm{X} 3+9,750 \mathrm{X} 4
$$

1. Konstanta sebesar 5096,456 hal ini menunjukkan bahwa apabila semua variabel independent (CR, EPS, ROI, dan ROE) bernilai 0, maka harga saham akan tetap bernilai Rp. 5096,456.

2. Variabel CR (X1) mempunyai koefisien regresi bernilai negatif sebesar -111,543. Hal ini menunjukkan bahwa setiap penambahan satu kali CR maka akan menurunkan harga saham sebesar Rp 111,543 dengan asumsi variabel lain constan.

3. Variabel EPS (X2) mempunyai koefisien regresi bernilai positif sebesar 44,060. Hal ini menunjukkan bahwa setiap penambahan satu kali EPS maka akan meningkatkan harga saham sebesar Rp 44,060 dengan asumsi variabel variabel lain constan.

4. Variabel ROI (X3) mempunyai koefisien regresi bernilai negatif sebesar -149,140. Hal ini menunjukkan bahwa setiap penambahan satu kali CR maka akan menurunkan harga saham sebesar Rp 149,140 dengan asumsi variabel lain constan.

5. Variabel ROE (X4) mempunyai koefisien regresi bernilai positif sebesar 9,750. Hal ini menunjukkan bahwa setiap penambahan satu kali ROE maka akan meningkatkan harga saham sebesar Rp 9,750 dengan asumsi variabel variabel lain constan.

\section{Penguji Hipotesis}

Dari persamaan regresi data panel, selanjutnya diadakan pengujian hipotesis, diantaranya ialah: a) Uji-t (uji hubungan secara parsial), b) Uji-F (uji hubungan secara simultan), c) Uji R² (koefisien determinasi). Uji statistik $\mathrm{t}$ pada dasarnya menunjukkan seberapa jauh hubungan masing-masing variabel independen secara individual dalam menerangkan variasi variabel dependen.

Tabel 11. Hasil Uji-t

\begin{tabular}{|c|c|c|c|c|c|}
\hline \multirow{2}{*}{\multicolumn{2}{|c|}{ Model }} & \multicolumn{2}{|c|}{ Unstandardized Coefficients } & \multirow[b]{2}{*}{$\mathrm{T}$} & \multirow[b]{2}{*}{ Sig. } \\
\hline & & $\mathrm{B}$ & Std. Error & & \\
\hline \multirow[t]{5}{*}{1} & (Constant) & 5096,456 & 1127,517 & 4,520 &, 000 \\
\hline & $\mathrm{CR}$ & $-111,543$ & 354,261 &,- 315 & ,754 \\
\hline & EPS & 44,060 & 207,649 & 212 & 833 \\
\hline & ROI & $-149,140$ & 667,254 &,- 224 & 824 \\
\hline & ROE & 9,750 & 222,020 &, 044 & ,965 \\
\hline
\end{tabular}

a. Dependent Variable: HargaSaham

Sumber : Hasil Olah Data 2021

berikut :

Berdasarkan hasil pengujian tersebut maka dapat dijelaskan pengaruh antar variabel sebagai

1. Variabel CR (X1) memiliki nilai $t_{\text {hitung }}$ sebesar,$- 315<t_{\text {tabel }} 1.67022$ dengan nilai signifikan sebesar 0,754 > 0,05 maka H0 diterima dan Ha ditolak, artinya variabel CR berpengaruh negatif dan tidak signifikan terhadap harga saham. 
2. Variabel EPS (X2) memiliki nilai $t_{\text {hitung }}$ sebesar $0,212<t_{\text {tabel }} 1.67022$ dengan nilai signifikan sebesar 0,833 > 0,05 maka H0 diterima dan Ha ditolak, artinya variabel EPS berpengaruh positif dan tidak signifikan terhadap harga saham.

3. Variabel ROI (X3) memiliki nilai $t$-hitung sebesar $-0,224<t_{\text {tabel }} 1.67022$ dengan nilai signifikan sebesar 0,824>0,05 maka H0 diterima dan Ha ditolak, artinya variabel ROI berpengaruh negatif dan tidak signifikan terhadap harga saham.

4. Variabel ROE (X4) memiliki nilai $t$-hitung sebesar $0,044<t_{\text {tabel }} 1.67022$ dengan nilai signifikan sebesar 0,965>0,05 maka H0 diterima dan Ha ditolak, artinya variabel ROE berpengaruh positif dan tidak signifikan terhadap harga saham.

\section{a. Uji F (Uji Hubungan Secara Simultan)}

Tabel 12. Hasil Uji F

\begin{tabular}{|l|c|c|c|c|c|c|}
\hline Model & Sum of Squares & df & Mean Square & F & Sig. \\
\hline \multirow{3}{*}{1} & Regression & 107382983,426 & 4 & 26845745,856 &, 986 &, $422^{\mathrm{b}}$ \\
\cline { 2 - 7 } & Residual & 1634173706,112 & 60 & 27236228,435 & & \\
\cline { 2 - 7 } & Total & 1741556689,538 & 64 & & & \\
\hline
\end{tabular}

Berdasarkan tabel 11 diperoleh nilai Fhitung 0,986 < Ftabel 2,25 dengan siginifikan 0,422 > 0,05 dengan demikian Ho diterima dan Ha ditolak, artinya secara simultan Variabel CR, EPS, ROI, dan ROE berpengaruh negatif dan tidak signifikan terhadap harga saham.

\section{b. Uji R $\mathbf{R}^{2}$ (Koefisien Determinasi)}

\begin{tabular}{|l|r|r|r|r|r|}
\hline Model & R & R Square & Adjusted R Square & $\begin{array}{c}\text { Std. Error of the } \\
\text { Estimate }\end{array}$ & Durbin-Watson \\
\hline 1 & \multicolumn{2}{|r|}{, 062} &,- 001 & 5218,834 &, 939 \\
\hline a. Predictors: (Constant), ROE, CR, EPS, ROI
\end{tabular}

Sumber : Hasil Olah Data 2021

Berdasarkan tabel tersebut dapat diketahui bahwa nilai R Square sebesar 0,062 atau 0,062 X $100 \%=0,62 \%$. Artinya CR, EPS, ROI, dan ROE secara simultan memberikan pengaruh/kontribusi terhadap harga saham sebesar 0,62\% sedangkan sisanya yaitu 99,38\% dijelaskan oleh faktor lain di luar variabel.

\section{b) Pembahasan Penelitian}

1. Pengaruh Current Ratio (CR) Terhadap Harga Saham.

Dalam suatu perusahaan Current Ratio merupakan salah satu rasio yang paling umum digunakan untuk mengukur likuiditas atau kemampuan perusahaan untuk menutupi kewajiban jangka pendek. Pada hasil menelitian ini Current Ratio (CR) berpengaruh negatif dan tidak signifikan terhadap harga saham pada perusahaan manufaktur sub sektor makanan dan minuman yang terdaftar di bursa efek Indonesia. Hal ini disebabkan karena investor cenderung melihat atau lebih mempertimbangkan rasio lain dalam pengambilan keputusan dalam berinvestasi saham, investor tidak memperdulikan kewajiban jangka pendek pada perusahaan tersebut selama tidak mengalami kerugian, sehingga para investor tetap membeli saham namun dengan mempertimbangkan rasio lain pada perusahaan tersebut. Hasil penelitian ini sesuai dengan penelitian yang dilakukan oleh Adipalguna \& Suarjaya, (2017) yang menyatakan bahwa likuiditas (Current Ratio) tidak berpengaruh signifikan terhadap harga saham pada perusahaan LQ45 di Bursa Efek Indonesia. Juga didukung oleh penelitian Sunaryo (2020), Likuiditas (Current Ratio) tidak berpengaruh signifikan terhadap Harga Saham. Selanjutnya dibuktikan dengan Nur"aidawati Siti (2018) Current Ratio (CR) berpengaruh negatif dan tidak signifikan terhadap harga saham. 
2. Pengaruh Earning Per Share (EPS) terhadap harga saham.

Pada hasil menelitian ini Earning Per Share (EPS) berpengaruh positif dan tidak signifikan terhadap harga saham pada perusahaan manufaktur sub sektor makanan dan minuman yang terdaftar di bursa efek Indonesia. Ini berarti bahwa investor tidak melihat EPS sebagai keputusan untuk membeli saham, sesuai dengan penelitian yang dilakukan oleh Cholidia (2017) bahwa investor cenderung tidak menggunakan analisis fundamental dalam pengambilan keputusan melainkan investor menggunakan kelompok referensi, pengalaman dan mengikuti pergerakan Bandar (spekulasi) dalam berinvestasi menunjukkan bahwa faktor psikologi dari investor mengambil peranan yang cukup penting dalam pengambilan keputusan investasi. Hasil penelitian ini konsisten dengan penelitian yang dilakukan oleh Novasari(2013), Anita dan Pavitra (2014), yang menegaskan bahwa EPS tidak memiliki pengaruh yang signifikan terhadap harga saham.

3. Pengaruh Return On Investmen (ROI) terhadap harga saham.

Hasil penelitian ini menunjukkan bahwa Return on Investment (ROI) berpengaruh negative dan tidak signifikan terhadap harga saham. Menurut Setyono \& Sulasmiyati (2017) ROI yang rendah tidak selalu buruk, karena hal ini disebabkan oleh keputusan manajemen perusahaan yang sengaja menggunakan utang dalam jumlah yang besar, beban bunga yang tinggi menyebabkan laba bersih menjadi relatif rendah. Sehingga, meskipun ROI mengalami fluktuasi harga saham tidak terpengaruh. Hasil penelitian ini tidak sejalan dengan hasil penelitian sebelumnya yang dilakukan oleh Amalia (2016) yang hasilnya secara parsial variabel ROI berpengaruh positif dan signifikan terhadap variabel harga saham. Akan tetapi Hasil penelitian ini di dukung dengan penelitian yang dilakukan oleh Abid (2006) yang hasilnya secara parsial variabel ROI berpengaruh negatif terhadap harga saham.

4. Pengaruh Return On Ekuity (ROE) terhadap Harga Saham.

Berdasarkan pengujian parsial variabel ROE berpengaruh positif dan tidak signifikan terhadap harga saham. Ini berarti bahwa investor tidak melihat ROE sebagai salah satu alasan untuk membeli saham sesuai dengan penelitian yang dilakukan oleh Cholidia (2017) bahwa investor cenderung tidak menggunakan analisis fundamental dalam pengambilan keputusannya melainkan menggunakan kelompok referensi, pengalaman dan mengikuti pergerakan bandar (spekulasi) dalam berinvestasi, menunjukkan bahwa faktor psikologi dari investor mengambil peranan yang cukup penting dalam pengambilan keputusan investasi.

\section{Simpulan dan Saran}

Berdasarkan hasil penelitian dan pembahasan, maka dapat ditarik simpulan bahwa secara parsial variabel CR, EPS, ROI, dan ROE tidak berpengaruh signifikan terhadap harga saham pada perusahaan manufaktur sub sector makanan dan minuman di Bursa Efek Indonesia (BEI) tahun 20152019. Secara simultan variabel CR, EPS, ROI, dan ROE berpengaruh negatif dan tidak signifikan terhadap harga saham pada perusahaan manufaktur sub sector makanan dan minuman di Bursa Efek Indonesia (BEI) tahun 2015-2019. Oleh karenanya maka penulis memberikan beberapa saran saran bagi penelitian selanjutnya yaitu bagi Peneliti Selanjutnya sebaiknya meneliti faktor-faktor lain yang mempengaruhi harga saham selain rasio keuangan yang telah diteliti oleh penulis dan diharapkan agar menggunakan seluruh indikator dari masingmasing rasio keuangan. Serta menggunakan lebih banyak lagi perusahaan baik pada sektor rokok maupun perusahaan pada sektor lain yang terdaftar di Bursa Efek Indonesia sehingga memungkinkan dapat mengambil kesimpulan yang lebih baik. Adapun bagi Perusahaan, Diharapkan perusahaan manufaktur sub sektor makanan dan minuman dapat menjaga dan meningkatkan profitabilitasnya dengan cara menggunakan aktiva yang dimiliki sebaik mungkin dan meningkatkan volume pemasaran agar memperbanyak penghasilan dan mengurangi biaya operasional pada perusahaan. Serta diharapkan untuk menjaga kestabilan antara likuiditas dan profitabilitas dengan cara mengelola aktiva lancar perusahaan dengan baik agar dapat membayar kewajiban jangka pendeknya namun tetap menghasilkan laba yang besar agar para investor tertarik untuk menanamkan modalnya pada perusahaan manufaktur sub sektor makanan dan minuman sehingga harga sahamnya pun meningkat. 


\section{DAFTAR PUSTAKA}

Abid, D. (2006). Pengaruh EPS, ROI, dan ROE Terhadap Perubahan Harga Saham Pada Perusahaan Sektor Manufaktur Pada Bursa Efek Jakarta (BEJ). Jurnal Fordema, 6, 51-62.

Adipalguna, I. G. N. S., \& Suarjaya, A. A. G. (2017). Pengaruh likuiditas, solvabilitas, aktivitas, profitabilitas, dan penilaian pasar terhadap harga saham perusahaan lq45 di bei. Udayana University.

Agustina, T., Gerhana, W., \& , S. (2020). The Effect of Locus of Control, Learning, and Adversity Quotient towards Micro Business Success (Study on Entrepreneurship under Foster Group of the Banjarmasin Regional Government). Journal of Wetlands Environmental Management. https://doi.org/10.20527/jwem.v8i1.215

Amalia, H. S. (2016). Analisis pengaruh earning per share, return on investment, dan debt to equity ratio terhadap harga saham perusahaan farmasi di bursa efek indonesia. Jurnal Manajemen Dan Akuntansi, 11(2).

Apriliana, E. (2019). Pengaruh Tipe Industri, Kinerja Lingkungan, Dan Profitabilitas Terhadap Carbon Emission Disclosure. WIDYAKALA JOURNAL. https:// doi.org/10.36262/widyakala.v6i1.149

Arfah, A., \& Aditya, H. P. K. P. (2019). Analysis of Productivity and Distribution of Female Workers in FB's Industries. Journal of Distribution Science, 17(3), 31-39. https://doi.org/10.15722/jds.17.03.201903.31

Asna, \& Graha, A. N. (2006). Analisis Pengaruh Rasio Kuangan terhadap Return Saham Perbankan yang Terdaftar di Bursa Efek Indonesia. Research Gate, 2(3), 192-212.

Broadstock, D. C., Chan, K., Cheng, L. T. W., \& Wang, X. (2020). The role of ESG performance during times of financial crisis: Evidence from COVID-19 in China. Finance Research Letters, June, 101716. https://doi.org/10.1016/j.frl.2020.101716

Cholidia, R. (2017). Perilaku Investor dalam Pengambilan Keputusan Investasi di Pasar Modal (Studi Kasus pada Investor Saham Individu di Bandar Lampung).

Darmadji, T., \& Hendy, M. F. (2006). Pasar Modal Di Indonesia: Pendidikan Tanya Jawab. Edisis Kelima, Salemba Empat, Jakarta.

Edwar, D. Y. (2016). Pengaruh car dan ldr terhadap return on assets. IV(2).

Eprima Dewi, L., Trisna Herawati, N. S., \& Gede Erni Sulindawati, L. S. (2015). Analisis Pengaruh NIM, BOPO, LDR, DAN NPL Terhadap Profitabilitas (Studi Kasus Pada Bank Umum Swasta Nasional Yang Terdaftar Pada Bursa Efek Indonesia Periode 2009-2013 ). E-Jurnal S1 Ak. Universitas Pendidikan Ganesha Jurusan Akuntansi Program S1, 3(1).

Ghozali, I. (2013). Aplikasi Analisis Multivariate Dengan Program IBM dan SPSS. In aplikasi analisis multivariate dengan program ibm spss 19 (p. 113). https:/ / doi.org/10.2307/1579941

Guerrazzi, M. (2015). Animal spirits, investment and unemployment: An old Keynesian view of the Great Recession. EconomiA, 16(3), 343-358. https:/ / doi.org/10.1016/j.econ.2015.09.002

Hery. (2016). Analisis Laporan Keuangan. In Analisis Laporan Keuangan (p. 4).

Ishak, A., \& Luthfi, Z. (2011). Pengaruh Kepuasan dan Kepercayaan Konsumen terhadap Loyalitas. Jurnal Siasat Bisnis, 15(1), 55-66.

Kewal, S. S. (2012). Pengaruh inflasi, suku bunga, kurs, dan pertumbuhan PDB terhadap indeks harga saham gabungan. Jurnal Economia, 8(1), 53-64.

Kim, J. (2020). When Organizational Performance Matters for Personnel Decisions: Executives' Career Patterns in a Conglomerate. Management Accounting Research, December 2018, 100695. https://doi.org/10.1016/j.mar.2020.100695

Lukiana, N. (2013). Implementasi Rasio Keuangan Untuk Menilai Kinerja Keuangan. Wiga: Jurnal Penelitian Ilmu Ekonomi, 3(2), 54-69.

Lynch, J., Mason, R. J., Beresford, A. K. C., \& Found, P. A. (2012). An examination of the role for Business Orientation in an uncertain business environment. International Journal of Production Economics, 137(1), 145156. https://doi.org/10.1016/J.IJPE.2011.11.004

Magrizos, S., Apospori, E., Carrigan, M., \& Jones, R. (2020). Is CSR the panacea for SMEs? A study of socially responsible SMEs during economic crisis. European Management Journal, 39(2), 291-303. https://doi.org/10.1016/j.emj.2020.06.002

Mait, H. A., Laporan Keuangan, A., Andres Maith Fakultas Ekonomi dan Bisnis, H., \& Akuntansi Universitas Sam Ratulangi Manado, J. (2013). Analisis Laporan Keuangan Dalam Mengukur Kinerja Keuangan Pada Pt. Hanjaya Mandala Sampoerna TBK. Jurnal EMBA, 6191(3), 619-628. https://media.neliti.com/media/publications/1681-ID-analisis-laporan-keuangan-dalam-mengukurkinerja-keuangan-pada-pt-hanjaya-mandal.pdf

Mappamiring, M., \& Putra, A. H. P. K. (2021). Understanding Career Optimism on Employee Engagement: Broaden-Built and Organizational Theory Perspective. Journal of Asian Finance, Economics and Business, 8(2), 0605-0616. https://doi.org/10.13106/jafeb.2021.vol8.no2.0605

Martani, D., \& Khairurizka, R. (2009). The effect of financial ratios, firm size, and cash flow from operating activities in the interim report to the stock return. Chinese Business Review, 08(06), 44-55. https://doi.org/10.17265/1537-1506/2009.06.005

Morris, R. D. (1987). Signalling, agency theory and accounting policy choice. Accounting and Business Research, 
18(69), 47-56.

Öztürk, H. (2017). The Relationship Between Earnings-to-Price, Current Ratio, Profit Margin and Return: An Empirical Analysis on Istanbul Stock Exchange. Accounting and Finance Research, 7(1), 109. https://doi.org/10.5430/afr.v7n1p109

Saerang, A. M. M., \& P.E., S. S. P. D. (2010). Pengaruh Capital Adequacy Ratio (CAR), BOPO, dan Non Performing Loan (NPL) terhadap kinerja keuangan perbankan di Indonesia. E-Journal Unsrat, 52-66.

Setyono, R. A., \& Sulasmiyati, S. (2017). Pengaruh Leverage, Nilai Pasar Dan Profitabilitas Terhadap Future Investment (Studi pada Perusahaan Sub Sektor Makanan dan Minuman yang terdaftar di Bursa Efek Indonesia Periode 2012-2015). Jurnal Administrasi Bisnis, 47(2), 94-102.

Sugiyono. (2014). Metode Penelitian Pendidikan Pendekatan Kuantitatif, Kualitatif dan R\&D. In Metode Penelitian Pendidikan Pendekatan Kuantitatif, Kualitatif Dan RED. https://doi.org/10.1007/s13398-014-0173-7.2

Sukirno, S. (2003). Pengantar Teori Mikroekonomi. In Computer. https://doi.org/10.1038/cddis.2011.1

Sunaryo, D. (2020). Pengaruh Likuiditas Dan Profitabilitas Terhadap Harga Saham Pada Perusahaan Manufaktur Sub Sektor Makanan Dan Minuman Yang Terdaftar Di Bursa Efek Indonesia (Bei) Periode 2009-2018. Jurnal Ilmiah Ekonomi Dan Bisnis Triangle, 1(3), 30-44.

Tahir, M., \& Mushtaq, M. (2016). Determinants of Dividend Payout: Evidence from listed Oil and Gas Companies of Pakistan. The Journal of Asian Finance, Economics and Business, 3(4), 25-37.

Tangngisalu, J., Mappamiring, M., Andayani, W., Putra, M. Y., \& Kusuma, A. H. P. (2020). CSR and Firm Reputation from Employee Perspective. Journal of Asian Finance, Economics and Business, 7(10), 171-182.

W.Wahyuni. (2012). Kajian Teori Return Of Asset. http://eprints.uny.ac.id/8032/3/BAB 2-09409131016.pdf

Yanikkaya, H., Gumus, N., \& Pabuccu, Y. U. (2018). How profitability differs between conventional and Islamic banks: A dynamic panel data approach. Pacific-Basin Finance Journal, 48, 99-111. https://doi.org/https://doi.org/10.1016/j.pacfin.2018.01.006 